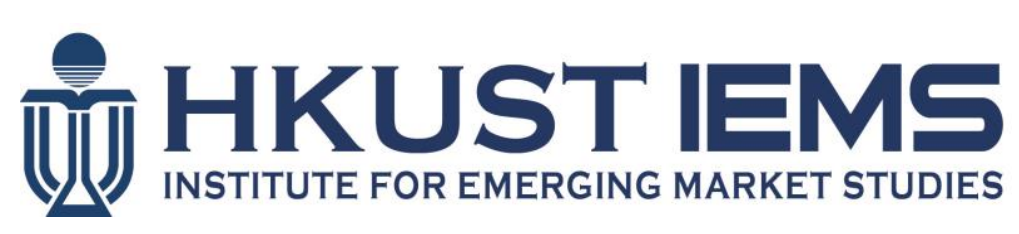

\title{
Input-Trade Liberalization and Markups
}

\author{
Haichao FAN, Yao Amber LI, Tuan Anh LUONG
}

HKUST IEMS Working Paper No. 2015-26

May 2015

\begin{abstract}
HKUST IEMS working papers are distributed for discussion and comment purposes. The views expressed in these papers are those of the authors and do not necessarily represent the views of HKUST IEMS.
\end{abstract}

More HKUST IEMS working papers are available at: 


\title{
Input-Trade Liberalization and Markups
}

\author{
Haichao FAN, Yao Amber LI, Tuan Anh LUONG
}

HKUST IEMS Working Paper No. 2015-26

May 2015

\begin{abstract}
This paper presents theory and evidence from Chinese firm-product data that, given firm productivity, trade liberalization increases product markups. This finding calls for a reconsideration of the well-established imports-as-market-discipline hypothesis. This paper further verifies underlying mechanisms behind this finding: input tariff reductions decrease marginal costs, and tariff effects on markup adjustments are more profound among firms of higher import dependence. By comparing results for two trade regimes -- ordinary trade (wherein firms pay import tariffs to import) and processing trade (wherein firms are not subject to import tariffs), this paper finds that the aforementioned effects only apply to ordinary trade.
\end{abstract}

\section{Authors' contact information}

Haichao Fan

School of International Business Administration

Shanghai University of Finance and Economics

T: +86 21-65907041

E: fan.haichao@mail.shufe.edu.cn

W: http://fanhaichao.weebly.com

Yao Amber Li

Department of Economics and Faculty Associate of HKUST IEMS

The Hong Kong University of Science and Technology

T: +85223587605

E: yaoli@ust.hk

W: http://ihome.ust.hk/ yaoli

Tuan Anh Luong

School of International Business Administration

Shanghai University of Finance and Economics

E: luong.tuananh@mail.shufe.edu.cn 


\title{
Input-Trade Liberalization and Markups*
}

$\begin{array}{ccc}\text { Haichao Fan } & \text { Yao Amber Li } & \text { Tuan Anh Luong } \\ \text { SUFE } & \text { HKUST } & \text { SUFE }\end{array}$

This Version: March 2015

\begin{abstract}
This paper presents theory and evidence from Chinese firm-product data that, given productivity, trade liberalization via input tariff reductions induces an incumbent importer/exporter to increase product markups. This finding calls for a reconsideration of the well-established imports-as-market-discipline hypothesis, which states that a higher volume of imports intensifies competition and hence decreases the market power of a firm. This paper presents further empirical evidence to verify underlying mechanisms behind this finding: input tariff reductions decrease marginal costs, and tariff reduction effects on markup adjustments are more profound among firms of higher import dependence. Moreover, this paper exploits unique features of Chinese data by comparing results for two trade regimes - ordinary trade (wherein firms pay import tariffs to import) and processing trade (wherein firms are not subject to import tariffs). While the aforementioned effects of input-trade liberalization and mechanisms only apply to ordinary trade, processing trade samples are used in a placebo test. The paper also shows that more productive firms charge higher markups for products. These findings are robust to various estimation specifications and alternative markup measures.
\end{abstract}

Keywords: Trade liberalization; Input tariff; Markup; Marginal cost; Ordinary trade; Processing trade; Output tariff

JEL: F12, F14, L11

*We thank Meredith Crowley, Kyle Handley, Frederic Warzynski, Larry Qiu, Miaojie Yu, and the seminar participants at Shanghai University of Finance and Economics and Peking University for helpful comments and suggestions. Yao Amber Li gratefully acknowledges financial support from the Research Grants Council of Hong Kong, China (General Research Funds and Early Career Scheme GRF/ECS Project no. 646112). All of the remaining errors are our own.

${ }^{\dagger}$ Fan: School of International Business Administration, Shanghai University of Finance and Economics, Shanghai, China. Email: fan.haichao@mail.shufe.edu.cn. Tel: (86)21-65907041.

${ }^{\ddagger} \mathrm{Li}$ : Department of Economics and Faculty Associate of the Institute for Emerging Market Studies (IEMS), Hong Kong University of Science and Technology, Clear Water Bay, Kowloon, Hong Kong SAR, China. Email: yaoli@ust.hk. Tel: (852)2358 7605; Fax: (852)2358 2084. Research Affiliate of the China Research and Policy Group at University of Western Ontario.

${ }^{\S}$ Luong: School of International Business Administration, Shanghai University of Finance and Economics, Shanghai, China. Email: luong.tuananh@mail.shufe.edu.cn 


\section{Introduction}

The notion that trade liberalization intensifies market competition is a widely held assumption in the international trade literature (Helpman and Krugman, 1989). The principle states that trade liberalization reforms force domestic firms to behave more competitively, decreasing the market power of individual firms. Helpman and Krugman deem this principle "the oldest insight in this area (of trade policy and imperfect competition)". This phenomenon is referred to by Levinsohn (1993) as the imports-as-market-discipline hypothesis, which has been tested extensively in the literature, from early works based on calibrated simulation models to empirical studies that employ econometric estimations. ${ }^{1}$ A recent work by de Blas and Russ (forthcoming) also supports the hypothesis that imports render firms more competitive and cause firms to charge lower markups.

However, other recent studies report mixed results that contradict this hypothesis. For example, Konings, Van Cayseele and Warzynski (2001) show that import penetration has no significant effect on firm markups and even increases markups in the Netherlands. Using EU manufacturing data, Chen, Imbs and Scott (2009) find short-term evidence of a standard pro-competitive effect causing markups to decline with trade openness, though they also report weak long-term effects that are more ambiguous and that may even prove anti-competitive. Moreover, while most of the aforementioned papers focus on trade liberalization in the final goods market, the focus of productivity and trade liberalization studies has shifted toward an exploration of tariff reduction effects on imported intermediate inputs (e.g., Amiti and Konings, 2007; Goldberg et al., 2010; Topalova and Khandelwal, 2011; Yu, forthcoming). This calls for additional studies that revisit the imports-as-market-discipline hypothesis under input-trade liberalization, and this paper aims to contribute to this area.

This paper examines whether lower tariffs on imported intermediates cause firms to adjust markups of exported goods that they export and the direction of such adjustments. This relationship between trade liberalization and product markup is particularly relevant to examine in the case of developing countries such as China. This is true because the imports-as-market-discipline phenomenon is frequently deemed especially important in developing countries, where previously protected domestic markets typically support fewer firms (see Levinsohn (1993) and Rodrik (1988) for a discussion). Moreover, firm responses to trade reforms regarding how firms may adjust their market power and underlying markups and marginal costs are essential in welfare analysis. Therefore, to address firm markup adjustments as responses to trade liberalization, we present a theory based on evidence from highly disaggregated Chinese merged data on firm production and firm-product trade, wherein input tariff reductions caused Chinese exporters to increase

\footnotetext{
${ }^{1}$ See Levinsohn (1993) for a more comprehensive literature review of earlier studies on this topic.
} 
markups of exported goods.

As a condition of China's accession to the World Trade Organization (WTO) in December of 2001, import tariffs imposed by China on imported goods were significantly decreased. In particular, the average input tariffs dropped by approximately $40 \%$ from 2000 to 2006. Meanwhile, Chinese export tariffs did not change much when China joined the WTO, as China long enjoyed MFN treatment from major trading partners prior to her WTO accession. This has resulted in arguably unilateral trade liberalization in China (Fan, Li and Yeaple, forthcoming). This unilateral feature of Chinese trade liberalization serves as a quasi-natural trade reform that allows us to estimate the effect of import tariff reductions on firm market power.

The use of Chinese data is also advantageous given its distinction between two trade regimes: ordinary trade (wherein firms pay import tariffs to import) and processing trade (wherein firms are not subject to import tariffs). More than 50 percent of transactions carried out in Chinese trade involve processing trade mechanisms, ${ }^{2}$ thus uniquely enabling us to identify specific input-trade liberalization (via input tariff reductions) effects on firm markup adjustments. When we examine input tariff effects on ordinary firm markups, processing trade observations may be used as a placebo sample to determine whether such effects apply to processing trade firms due to the absence of input tariff reduction mechanisms. To be consistent with the firm-product transaction-level customs data that distinguish the trade regimes (ordinary trade versus processing trade), we use merged firm-product data to estimate firm-product markups based on an augmented approach of De Loecker et al. (2014). ${ }^{3}$

We first document two stylized facts regarding the relationship between trade liberalization in China by accession to the WTO and firm-product markup adjustments among ordinary and processing incumbent Chinese exporters. We show that Chinese trade liberalization is largely driven by input-trade liberalization and find that ordinary trade firms raise markup levels with input tariff reductions during trade liberalization, while processing trade firms do not.

We substantiate these facts using a simple heterogeneous firm and variable markup model. The model predicts that controlling for productivity, a reduction in import tariffs enables an ordinary firm to become more efficient from access to cheaper and superior inputs. Moreover, we show that a more efficient firm charges higher markup. These

\footnotetext{
${ }^{2}$ Processing trade is a prevalent feature among Chinese trading firms (see Yu (forthcoming) and Manova and $\mathrm{Yu}$ (2014)) for more details).

${ }^{3}$ According to the firm-level production data, we cannot distinguish the processing trade and ordinary trade. Firm-product customs data provides the information of trade regime, which help us distinguish each transaction as processing trade or ordinary trade. If we classify processing and ordinary trade at firm level, then more than $40 \%$ of firms are hybrid firms, i.e., the firms that conduct both processing trade and ordinary trade transactions. Therefore, it is better to use firm-product markup instead of firm markup to test the difference between ordinary and processing trade in this context.
} 
results imply that an ordinary trade firm would set a higher markup for its exported products following a reduction in input tariffs. A processing trade firm, however, does not pay import tariffs, which is the typical practice in China. Hence, a processing trade firm would not be affected by a change in marginal costs due to input tariff reductions.

As predicted by our model, the empirical findings show that only ordinary trade observations significantly respond to input tariff reductions by increasing markups while processing trade observations do not. We also test marginal cost effects and import dependence levels to confirm underlying mechanisms of our theoretical model. Our empirical results are robust to various estimation specifications and alternative measures of firm-product and firm-level markup.

This paper contributes to extensive literature on trade liberalization effects on the efficient allocation of resources among firms (De Loecker et al., 2014; Arkolakis et al., 2012; among others). As De Loecker et al. (2014) noted, most previous studies in this field have only examined competitive effects of output tariff reductions, and input-trade liberalization effects have been studied less frequently. Our paper thus contributes to this literature by examining ordinary and processing Chinese firm-product export data together with production data to determine input tariff reduction effects on markups and marginal costs throughout Chinese input-trade liberalization.

Our paper also contributes to a large body of the literature that relates improved access to imported intermediate inputs to superior firm performance (e.g., improved total factor productivity (Amiti and Konings, 2007; Kasahara and Rodrigue, 2008; Halpern, Koren and Szeidl, 2011; Gopinath and Neiman, 2014), quality upgrading (Amiti and Khandelwal, 2013, Fan, Li and Yeaple, forthcoming), and expanded product scope (Goldberg et al., 2010)). Finally, we contribute to emerging literature that explores ordinary and processing trade firm behaviors in emerging markets (Yu, forthcoming; Manova and $\mathrm{Yu}, 2014$ ) by examining markup adjustment as an additional dimension of firm response.

The rest of the paper is organized as follows. Section 2 documents two stylized facts regarding input-trade liberalization and markup adjustment. Section 3 presents a simple theoretical model to describe the effect of tariff reductions on markups. Section 4 describes the identification strategy and data and measurements used, including the method of firm-product markup estimation. Section 5 presents econometric specifications and the main results. Section 6 presents additional robustness test results. The final section presents a conclusion. 


\section{Stylized facts}

This section documents two stylized facts concerning the relationship between Chinese input-trade liberalization and Chinese exporting firm markup. The firm-product markup estimation method is based on the methodology presented in De Loecker et al. (2014) and is described in greater detail in Section 4. Note that we categorize products under the HS6 product category.

Figure 1: China's import values (aggregate and by category, in trillion US dollar)

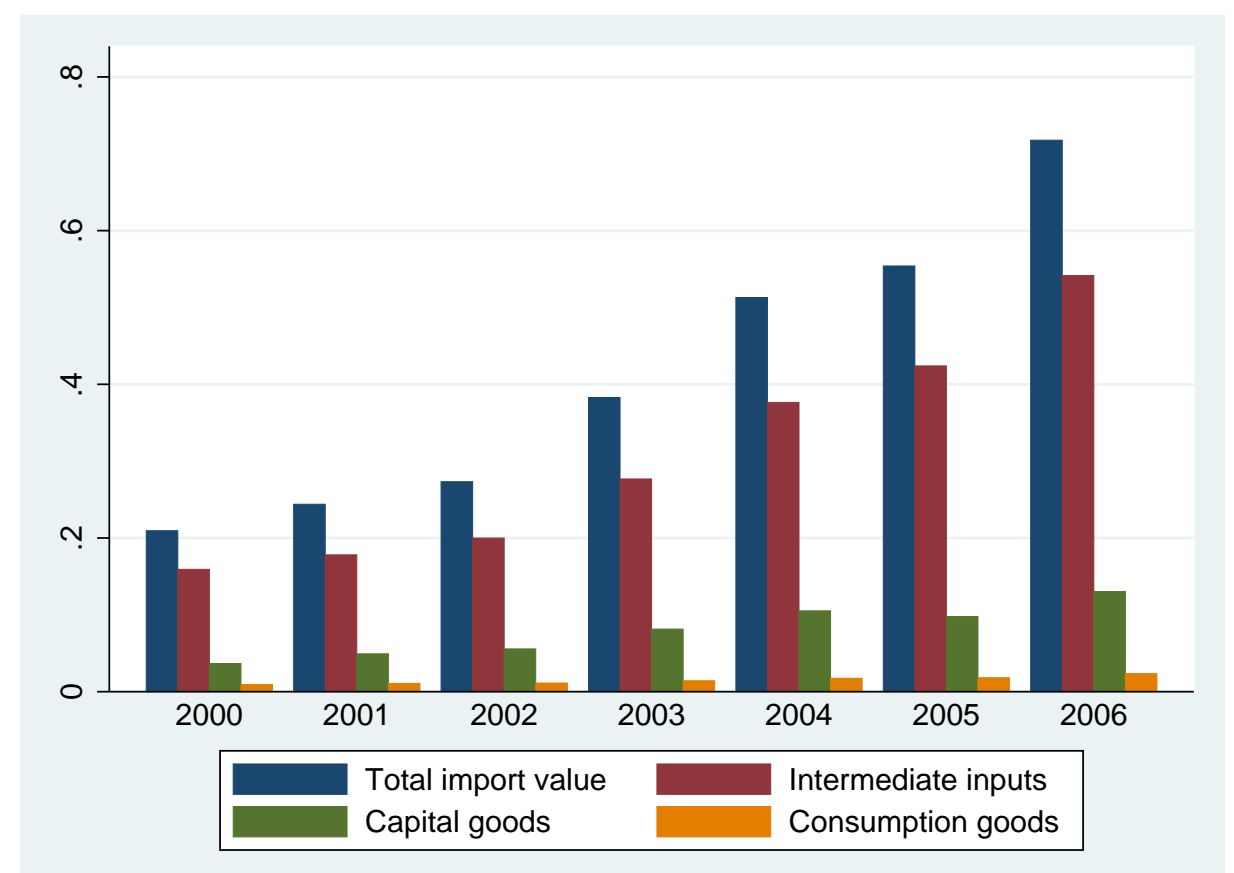

Notes: Import values are computed based on the whole Customs data. In this figure we do not distinguish ordinary/process trade. For ordinary trade, the pattern is similar and results are available upon request.

It is widely recognized that China has experienced substantial trade liberalization since joining the WTO in 2001. Trade liberalization has significantly affected the final and intermediate goods markets. We use the entire universe of Chinese customs data to plot aggregate import and import values by category (based on the BEA classification) (i.e., capital goods, intermediate goods, and consumption goods (final goods)) in Figure 1. Aggregate imports of Chinese firms have increased overtime: the total import value has more than tripled from 0.21 trillion US dollars in 2000 to 0.72 trillion US dollars in 2006. More importantly, the majority of Chinese imports are intermediate $(74 \%)$ and capital goods (19\%), and final goods account for only $4 \%$ of total imports. The share of final goods imports has remained stable overtime. ${ }^{4}$ This determines our first stylized fact:

\footnotetext{
${ }^{4}$ A fourth "uncertain" category accounts for approximately $3 \%$.
} 
Stylized fact 1 . Trade liberalization in China since its accession to the WTO has largely been driven by input-trade liberalization.

Figure 1 presents evidence that much of the rise in total imports stems from a surge in intermediate and capital good input imports, as these can both be broadly referred to as inputs. As a result, China serves as a good case study to examine input-trade liberalization impacts via input tariff reductions on firm market power, for which we use markups as a proxy.

To examine Chinese firm markup trends, we estimate firm-product markups using a slightly modified version of De Loecker et al. (2014)'s methodology based on features of Chinese data. This method examines multi-product firms in which different products can have different markups. To estimate firm-product markups, we must use the merged sample of manufacturing firms (with production data) rather than the entire universe of customs data (see Section 4 for a description of data used).

Figure 2: Markup Adjustments and Input Tariff Cuts (Ordinary Trade vs. Processing Trade)

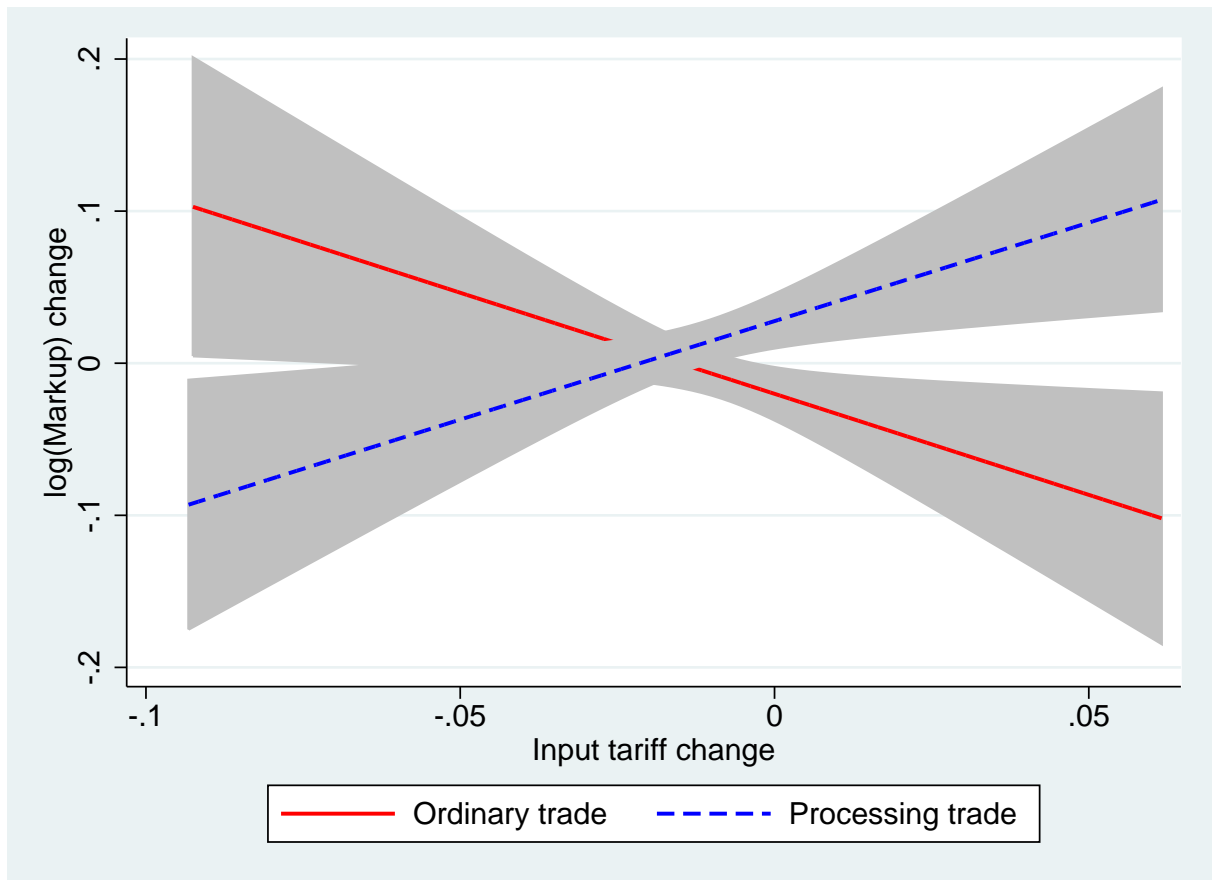

We then regress estimated firm-product markups on input tariffs, which are computed using product-level output tariffs and an input-output table for China (see input tariff computation provided in Section 4), and plot predicted markup adjustments at 90\% confidence intervals against input tariff cuts by trade regime in Figure 2. We find that input tariff effects on markups differ depending on whether ordinary or processing trade regimes are involved. For ordinary trade firms, input tariff reductions increase markups (i.e., firms facing larger input tariff cuts increase markups more), while for processing trade firms, this relationship is positive. This is perhaps attributable to the fact that 
processing trade firms are only affected by pro-competitive effects while ordinary trade firms are affected more by input tariff reductions that can offset markup reductions resulting from pro-competitive mechanisms, ultimately increasing markups. We thus summarize the second finding as follows:

Stylized fact 2. An ordinary trade firm raises its markups with input tariff reductions during trade liberalization, while a processing trade firm does not.

\section{A simple model}

In this section, we present a simple, partial equilibrium model of trade for heterogeneous firms to examine how import tariff reductions affect incumbent import/export firm markup adjustments. Our model examines intermediate input imports and marginal cost adjustments to show why firms facing import input tariff reductions increase markups during input-trade liberalization. In the model, each firm uses both domestic and imported intermediate inputs to produce final outputs.

\subsection{Consumers}

To accommodate variable markups in trade models with monopolistic competition, we employ a general demand system for differentiated goods proposed by Arkolakis et al. (2012)..$^{5}$ All consumers have the same preferences. If a consumer with income $w$ faces a schedule of prices $\boldsymbol{p} \equiv\left\{p_{\omega}\right\}_{\omega \in \Omega}$, her Marshallian demand for any differentiated good $\omega$ is given by

$$
\ln q_{\omega}\left(p_{\omega}, p^{*}(\boldsymbol{p}, w), w\right)=-\beta \ln p_{\omega}+\gamma \ln w+d\left(\ln p_{\omega}-\ln p^{*}(\boldsymbol{p}, w)\right)
$$

where $p^{*}(\boldsymbol{p}, w)$ is an aggregator that is symmetric in all prices $p_{\omega}$. This demand system has the following important properties (Arkolakis et al., 2012). First, the price elasticity $-\beta+d^{\prime}\left(\ln p_{\omega}-\ln p^{*}(\boldsymbol{p}, w)\right)$ is allowed to vary with prices, which will generate variable markups under monopolistic competition. Second, other prices only affect the demand for good $\omega$ through their effect on the aggregator $p^{*}(\boldsymbol{p}, w)$. This property brings the monopolistic competition to our model. Given existing parameter values in the literature, the following restrictions are imposed:

Assumption A1: The elasticity of demand must be higher than one, $\frac{\partial \ln q\left(p, p^{*}, w\right)}{\partial \ln p}<-1$.

\footnotetext{
${ }^{5}$ This demand system encompasses three proposed alternatives to generate variable markups: (i) separable, but non-CES utility functions, as in the pioneering work of Krugman (1979); (ii) a quadratic, but nonseparable utility function, as in Ottaviano, Tabuchi and Thisse (2002); and (iii) a translog expenditure function, as in Feenstra (2003).
} 
This assumption implies that the percentage change in quantity demanded is greater than that in price. Hence, as the price decreases, the total revenue increases, and vice versa. It is satisfied by all efficiency sorting Melitz-type model. ${ }^{6}$

Assumption A2: For all $x, d^{\prime \prime}(x)<0$.

This assumption is equivalent to the one that demand functions are log-concave (in log-prices) for all differentiated goods. It is satisfied by the demand systems considered in Krugman (1979), Ottaviano, Tabuchi and Thisse (2002), and Feenstra (2003).

\section{$3.2 \quad$ Firms}

Production.-The supply side is characterized by monopolistic competition. Each variety is produced by a single firm, and we focus on incumbent firms in the industry. Firms are heterogeneous in their initial, idiosyncratic productivity, $\varphi$. Each firm produces output according to the following production function:

$$
Y=\varphi\left(K^{a} L^{1-a}\right)^{1-\eta} Z^{\eta}
$$

where $Z$ denotes the intermediate inputs bundle, and $K$ and $L$ denote capital and labor inputs employed in the production. The intermediate inputs bundle $Z$ is assembled from a combination of a bundle of diverse intermediate inputs produced domestically, $D$, and another bundle of imported intermediate inputs, $M$, according to the CES aggregator:

$$
Z=\left(D^{\frac{\varsigma-1}{\varsigma}}+M^{\frac{\varsigma-1}{\varsigma}}\right)^{\frac{\varsigma}{\varsigma-1}}
$$

where $\varsigma$ is the elasticity of substitution between the bundles of imported and domestically produced inputs, and the input bundles themselves are also CES aggregates:

$$
\begin{aligned}
D & =\left(\int_{0}^{1} d_{l}^{\frac{\theta-1}{\theta}} d l\right)^{\frac{\theta}{\theta-1}}, \\
M & =\left(\int_{\Omega} m_{h}^{\frac{\theta-1}{\theta}} d h\right)^{\frac{\theta}{\theta-1}}
\end{aligned}
$$

where $d_{l}$ represents the firm's use of domestically produced inputs $l, m_{h}$ is the quantity of imported input $h$, and $\Omega$ is the constant set of foreign input varieties imported by the firm which is firm-specific. The elasticity of substitution $\theta>1$ is the same within domestic varieties and within foreign varieties. ${ }^{7}$

Import Decision.-Conditional on being an importer, the import decision a firm needs

\footnotetext{
${ }^{6}$ See a comprehensive review in Manova and Zhang (2012).

${ }^{7}$ This is just for simplification. We can also allow $\theta$ to be different for within domestic varieties and for within foreign varieties.
} 
to make is how much of each variety to import. To be simplified, we assume that the set of imported varieties is fixed. ${ }^{8}$

The firm chooses labor $L$, capital $K$, and the amount of domestic inputs $\left\{d_{l}\right\}$, given the wage rate $w$, the rental rate $r$, and the price of domestic intermediate input $\left\{p_{l}\right\}$. The firm $i$ also chooses the amount of each imported variety $m_{h}$, given the price $\left\{p_{h}\right\}$ and import tariff $\tau_{h}$ for each imported product $h$. The marginal cost of the inputs, $c$, satisfies:

$$
c=\frac{B^{\eta}}{\varphi} \frac{P_{V}^{1-\eta} P_{Z}^{\eta}}{\eta^{\eta}(1-\eta)^{1-\eta}}
$$

where $P_{V}=\frac{r^{a} w^{1-a}}{a^{a}(1-a)^{1-a}}$ is the price index for capital and labor, $P_{Z}=\left(\int_{0}^{1} p_{l}^{1-\theta}\right)^{\frac{1}{1-\theta}}$ denotes the domestic input price index, and $\frac{P_{V}^{1-\eta} P_{Z}^{\eta}}{\eta^{\eta}(1-\eta)^{1-\eta}}$ is the marginal cost index for a non-importing firm. The use of imported inputs leads to a cost-reduction factor $B \equiv\left(1+\left(P_{M} / P_{Z}\right)^{1-\varsigma}\right)^{\frac{1}{1-\varsigma}}$, where $P_{M}$ is the imported input price index:

$$
P_{M}=\left(\int_{\Omega}\left(\tau_{h} p_{h}\right)^{1-\theta}\right)^{\frac{1}{1-\theta}}
$$

\subsection{Firm's behavior}

Consider the optimization problem of a firm producing good $\omega$ in origin country $o$ and selling it in a destination country $d$. To simplify notation without risk of confusion, we suppress those product and country indexes. Let $p^{*}$ and $w$ denote the choke price and the wage in the destination country, respectively. Under monopolistic competition with segmented good markets and constant returns to scale, the firm chooses its market-specific price $p$ in order to maximize profits in the market

$$
\max _{p}(p-c) q\left(p, p^{*}, w\right)
$$

taking $p^{*}$ and $w$ as given. The associated first-order condition is

$$
\frac{p-c}{p}=-\frac{1}{\frac{\partial \ln q\left(p, p^{*}, w\right)}{\partial \ln p}}=\frac{1}{\beta-d^{\prime}\left(\ln p-\ln p^{*}(\boldsymbol{p}, w)\right)}
$$

We use $\mu=\ln (p / c)$ as our measure of firm-level markup. Marginal cost pricing corresponds to $\mu=0$. Combining the previous expression with equation (1), we can express

\footnotetext{
${ }^{8}$ If we allow the set of imported varieties to be changed, an input tariff reduction induces the firm to import more varieties under some assumptions according to Gopinath and Neiman (2014). Enlarging the set of imported varieties would decrease the marginal cost and further increase the markups which will be consistent with our later prediction.
} 
markup as the implicit solution of

$$
\mu=\ln \left(\frac{\beta-d^{\prime}(\mu-v)}{\beta-1-d^{\prime}(\mu-v)}\right)
$$

where $v=\ln \left(p^{*} / c\right)$ can be viewed as a measure of the efficiency of the firm relative to other firms in the industry. Whether markups are monotonically increasing in productivity depends on the monotonicity of $d^{\prime}$ (Arkolakis et al., 2012).

Lemma 1. A more efficient firm charges higher markups. ${ }^{9}$

Proof. Let's denote $f(\mu, \nu)=\mu-\ln \left(\frac{\beta-d^{\prime}(\mu-v)}{\beta-1-d^{\prime}(\mu-v)}\right)$

$$
\begin{aligned}
& f_{\mu}(\mu, \nu)=1+\left[\frac{1}{\beta-d^{\prime}(\mu-v)}-\frac{1}{\beta-1-d^{\prime}(\mu-v)}\right] d^{\prime \prime}(\mu-v) \\
& f_{\nu}(\mu, \nu)=-\left[\frac{1}{\beta-d^{\prime}(\mu-v)}-\frac{1}{\beta-1-d^{\prime}(\mu-v)}\right] d^{\prime \prime}(\mu-v)
\end{aligned}
$$

Note that $\beta-d^{\prime}(\mu-v)>\beta-1-d^{\prime}(\mu-v)>0$, where the last inequality follows from Assumption A1. Together with Assumption A2, it is clear that $f_{\mu}(\mu, \nu)>0$ and $f_{\nu}(\mu, \nu)<0$. Applying the implicit function theorem to the function $f(\mu, \nu)$ and knowing that our markup $\mu$ is a solution to this, we then have $\mu^{\prime}(\nu)=-\frac{f_{\mu}(\mu, \nu)}{f_{\nu}(\mu, \nu)}>0$.

During trade liberalization, a reduction in import tariff $\tau_{h}$ leads to a fall in the imported input price index $P_{M}$ and hence, the cost-reduction factor $B$. Equation (6) then implies that the marginal cost $c$ also falls. It in turn increases $\nu$, the efficiency of the firm relative to other firms. According to Lemma 1, we then have the following proposition:

Proposition 1. Given productivity, a reduction in import input tariff induces a firm to set a higher markup for its product. ${ }^{10}$

This proposition applies to the firm's product in general, and in particular, the firm's exported product. Given our focus is the incumbent importer/exporter, we will test this proposition using exported products in our empirical analysis.

\footnotetext{
${ }^{9}$ This lemma was earlier proved in Arkolakis et al. (2012), Appendix A.2 "Monotonicity of Markups".

${ }^{10}$ Our model setting belongs to efficiency sorting, which implies that a reduction in import tariff induces a decline in export prices. However, markups would increase. This perhaps appears in the short run. If time is sufficiently long, we can observe the quality adjustment mechanism and then the increase in export prices (Fan, Li and Yeaple, forthcoming). More importantly, introducing the quality mechanism would not affect our prediction about markup increase under input-trade liberalization, and it would even amplify the effect of tariff reductions on markup increase.
} 


\section{Identification and measurement}

In this section, we present our identification strategy, which takes advantage of differences between ordinary and processing trade. We then describe the data and measurements used in our empirical analysis.

\subsection{Identification strategy: ordinary trade vs. processing trade}

Processing trade is common in Chinese trading firms ( $\mathrm{Yu}$, forthcoming; Manova and $\mathrm{Yu}$, 2014). A Chinese firm can receive inputs from its trading partners, assemble them and export directly to its trading partners. This form of trade is referred to as "processing with supplied inputs" in custom documents. Alternatively, they may pay for imported inputs from foreign suppliers and export all processed goods, a strategy referred to as "processing with imported inputs". Both types of processing trade firms enjoy duty-free benefits. In the presence of processing trade, a firm can fall into one of the three categories: non-importing firm, ordinary importer and processing importer. As processing firms are not subject to any import tariffs, we expect that the marginal cost effect does not apply to them.

In this paper, we aim to identify differences between ordinary and processing trade, and Chinese data uniquely allow us to examine tariff reduction effects on both types of trade. Note that in this paper, we identify firm-product level trade types to avoid defining trade types at the firm level, as some firms allow for both ordinary and processing trade for various products (hybrid firms). Hybrid firms account for a particularly large proportion of the customs data: at the firm level, pure ordinary, pure processing, and hybrid firms account for $36.31 \%, 23.20 \%$, and $40.49 \%$, respectively. Examining ordinary and processing trade at the firm-product level thus allows us to clearly distinguish trade regimes according to customs transactions in congruence with our firm-product level markups. $^{11}$

\subsection{Firm-product trade data and firm-level production data}

To estimate firm-product markups, we must use firm-level data to measure firm attributes (e.g., TFP) and product-level trade data on export prices, export values and customs regimes. Therefore, we use a merged dataset based on two databases: (1) firm-productlevel trade data of each Chinese customs transaction, and (2) firm-level production data, collected and maintained by the National Bureau of Statistics of China (NBSC). Our

\footnotetext{
${ }^{11}$ It is still possible that the same firm-HS6 product pair involves both processing and ordinary trade when exporting to different destination markets, but the proportion of this kind of "hybrid" firm-product only accounts for $9.31 \%$ in our sample.
} 
sample period runs from 2000 to 2006 .

Firm-product-level trade data.-We use a Chinese transaction-level trade database provided by China's General Administration of Customs. These transaction-level trade data provide information on exporting and importing firms, product information at the HS 8-digit level and on source/destination countries, covering the universe of all Chinese exports and imports for 2000-2006. The database includes detailed information on each trade transaction, including import and export values, quantities, products, source and destination countries, firm contact records (e.g., company name, telephone, zip code, contact person), enterprise types (e.g., state owned, domestic private, foreign invested, and joint venture), and customs regimes (e.g., "Processing and Assembling" and "Processing with Imported Materials"). As processing trade regime firms are not subject to tariffs, we focus on ordinary trade regime firms, but using processing trade firms as a placebo test sample. We then aggregate transaction-level trade data to the firm-product level. Note that to ensure the consistency of product categorizations overtime, we aggregate HS8 products to the HS6 level. ${ }^{12}$ Therefore, in this paper, a product refers to a HS6 product category. Also note that we only focus on manufacturing products to maintain consistency with the second database of NBSC manufacturing firm production data. ${ }^{13}$

Firm-level production data.-To characterize firm attributes (e.g., TFP and capital intensity), we use NBSC firm-level production data drawn from annual surveys of Chinese manufacturing firms for all state-owned enterprises (SOEs) and non-state-owned enterprises with annual sales of at least five million RMB (Chinese currency). The NBSC database contains detailed firm-level data on Chinese manufacturing enterprises, including employment, capital stock, gross output, value added, and firm identification information (e.g., company name, telephone number, zip code, contact person, etc.). ${ }^{14}$ Due to cases of misreporting by some firms, we use the following protocols to remove unsatisfactory observations and construct our sample in accordance with Cai and Liu (2009) and General Accepted Accounting Principles: (i) total assets must be higher than liquid assets; (ii) total assets must be higher than total fixed assets; (iii) total assets must be higher than the net value of fixed assets; (iv) a firm's identification number cannot be missing and must be unique; and (v) the established time must be valid.

Matching the two databases.-We then match firm-product-level trade data of the Chinese Customs Database with the NBSC Database based on the contact information of manufacturing firms, as no consistent coding system of firm identity is available for

\footnotetext{
${ }^{12}$ At the HS8 level, Chinese customs officials often change codes, though the first six-digit HS code follows international standards. Hence, we convert HS 2002 codes into HS 1996 codes at the six-digit HS level based on UN Comtrade specifications.

${ }^{13}$ There are originally 20 sectors included in the UN list of HS product classifications (See http://unstats.un.org/unsd/tradekb/Knowledgebase/HS-Classification-by-Section). We omit sectors 1-3 (agricultural sectors), Sector 5 (the mining sector), and Sector 19 (arms and ammunition).

${ }^{14}$ This firm identification information is used to match the NBSC database with the customs database.
} 
these two databases. Our matching procedure is carried out in three steps: (1) by company name, (2) by telephone number and zip code, and (3) by telephone number and contact person name (see a detailed description of the matching process in Fan, Lai and $\mathrm{Li}$, forthcoming). Unlike the exporting and importing firms reported in the customs database, ${ }^{15}$, the matching rate of our sample (in terms of the number of firms) covers $45.3 \%$ of all exporters and $40.2 \%$ of all importers, corresponding to $52.4 \%$ of total export values and $42 \%$ of total import values reported by the Customs Database. ${ }^{16}$

\subsection{Measure of markup}

Our main measure of markup is at firm-product level and the estimation method is following De Loecker et al. (2014). Consider the following production function for firm $f$ to produce a product $h$ at time $t$ :

$$
Q_{f h t}=F_{t}\left(\boldsymbol{X}_{f h t}\right) \exp \left(\varphi_{f t}\right)
$$

where $Q_{f h t}$ is physical output and $\boldsymbol{X}_{f h t}$ is a vector of inputs. There are two assumptions about productivity. First, productivity $\varphi$ enters in log-additive form and is Hicks-neutral. Second, we assume that productivity is firm-specific. The second assumption follows a tradition in the trade literature that models firm-specific productivity together with firmproduct-specific demand shocks (e.g., Bernard, Redding and Schott, 2010).

We assume that producers minimize costs. Let $V_{f h t}$ denote the vector of variable inputs used by the firm to produce a product $h$. We use the vector $K_{f h t}$ to denote dynamic inputs of production which can include any input that faces adjustment costs, for instance, capital. We consider the firm's conditional cost function, conditioning on the set of dynamic inputs $K_{f h t}$. The associated Lagrangian function is:

$$
\begin{aligned}
L\left(V_{f h t}, K_{f h t}, \lambda_{f h t}\right) & =\sum_{v=1}^{V} P_{f h t}^{v} V_{f h t}^{v}+\sum_{d=1}^{D} r_{f h t}^{d} K_{f h t}^{d} \\
& +\lambda_{f h t}\left[Q_{f h t}-Q_{f h t}\left(V_{f h t}, K_{f h t}, \varphi_{f t}\right)\right]
\end{aligned}
$$

where $P_{f h t}^{v}$ and $r_{f h t}^{d}$ denote the firm's input prices for the variable inputs $v=1, \ldots, V$ and the prices of dynamic inputs $d=1, \ldots, D$, respectively. The first order condition for any variable input free of adjustment costs is:

$$
\frac{\partial L_{f h t}}{\partial V_{f h t}}=P_{f h t}^{v}-\lambda_{f h t} \frac{\partial Q_{f h t}(\cdot)}{\partial V_{f h t}}
$$

\footnotetext{
${ }^{15}$ As we merge the customs database with manufacturing firms listed in the NBSC database, we exclude all intermediary firms and trading companies listed in customs database.

${ }^{16}$ We do not compare our sample to the NBSC Database, as it does not contain any information on firm import statuses.
} 
where the marginal cost of production at a given level of output is $\lambda_{f h t}$ since $\partial L_{f h t} / \partial Q_{f h t}=$ $\lambda_{f h t}$. Rearranging terms and multiplying both sides by $V_{f h t} / Q_{f h t}$ yields the following expression:

$$
\frac{\partial Q_{f h t}(\cdot)}{\partial V_{f h t}} \frac{V_{f h t}}{Q_{f h t}}=\frac{1}{\lambda_{f h t}} \frac{P_{f h t}^{v} V_{f h t}}{Q_{f h t}}
$$

The left-hand side of the above equation represents the elasticity of output with respect to variable input $V_{f h t}$ (the "output elasticity"). The approach requires one freely adjustable input into production. In the current setting, there are frictions in adjusting capital. Define the markup $\mu_{f h t}$ as $\mu_{f h t}=\ln \left(P_{f h t} / \lambda_{f h t}\right),{ }^{17}$ where $P_{f h t}$ is the price for product $h$ produced by firm $f$ at time $t$. As De Loecker and Warzynski (2012) and De Loecker et al. (2014) show, the cost-minimization condition can be rearranged to write the markup for each product $h$ produced by firm $f$ at time $t$ as:

$$
\mu_{f h t}=\ln \left(\theta_{f h t}^{v}\left(\alpha_{f h t}^{v}\right)^{-1}\right)
$$

where $\theta_{f h t}^{v}$ denotes the output elasticity on variable input $V_{f h t}^{v}$ and $\alpha_{f h t}^{v}=\frac{P_{f h t}^{v} V_{f h t}^{v}}{P_{f h t} Q_{f h t}}$ is its expenditure share of revenue for each product $h$ produced by firm $f$ at time $t$. This expression forms the basis for our approach. To compute the markup, we need the output elasticity and the share of the input's expenditure in total sales.

Consider the log version of the general production function given in equation (9):

$$
q_{f h t}=f\left(x_{f h t} ; \beta\right)+\varphi_{f t}+\epsilon_{f h t}
$$

where lower case letters denote logs. The quantity of product $h$ by firm $f$ at time $t, q_{f h t}$, is produced using a set of firm-product-(country)-year specific inputs, $x_{f h t}$. The error term $\epsilon_{f h t}$ captures measurement error in recorded output as well unanticipated shocks to output. As noted earlier, the productivity term $\varphi_{f t}$ is assumed to vary at the firm level.

For multi-product firms, it is hard to identify how the inputs are allocated across different products within a firm due to data restriction. To understand this, denote the $\log$ of the share of input $X$ in the production of product $h$ as $\rho_{f h t}^{X}=x_{f h t}-x_{f t}$, for any input $X=\{L, M, K\}$, where $L$ is labor, $M$ is materials and $K$ is capital. We only observe firm-level inputs $X_{f t}$ and not how each of them is allocated across products. Substituting this expression into equation (12) yields:

$$
q_{f h t}=f\left(x_{f t} ; \beta\right)+\varphi_{f t}+A_{f h t}\left(\rho_{f h t}^{X} ; x_{f t} ; \beta\right)+\epsilon_{f h t}
$$

where $x_{f t}$ denotes the log of inputs $X_{f t}$. For multi-product firms, the production function

\footnotetext{
${ }^{17}$ Here we define markups in logarithm to be consistent with our previous model. This is slightly different with the definition in De Loecker and Warzynski (2012) where they do not take logarithm. Both approaches yield similar empirical results.
} 
contains an additional component in the error term, $A_{f h t}(\cdot)$, that will generally be a function of the unobserved input shares $\left(\rho_{f h t}^{X}\right)$, the firm level inputs $\left(x_{f t}\right)$ and the production function coefficients, $\beta$. In the case of a translog production function, the vector of log inputs $x_{f t}$ are labor, material and capital, their squares, and their interaction terms; the vector of coefficients is $\beta=\left(\beta_{l}, \beta_{m}, \beta_{k}, \beta_{l l}, \beta_{m m}, \beta_{k k}, \beta_{l m}, \beta_{l k}, \beta_{m k}\right)$. Based on the methodology of De Loecker and Warzynski (2012), we use the firm-level production survey data from the National Bureau of Statistics of China (NBSC) to estimate the production function coefficients, $\beta$, in the production function, $q_{f t}=f\left(x_{f t} ; \beta\right)+\varphi_{f t}+\epsilon_{f t}$ (see Appendix A for more details). Since we do not have quantity data, we use the deflated revenue of total sales to replace quantity. Therefore, in our estimation we use deflated revenue as proxy for $q_{f t} \cdot{ }^{18}$

Let $\rho_{f h t}=\ln \left(\frac{\tilde{X}_{f h t}}{\tilde{X}_{f t}}\right)$ be the input cost share of product $h$, where $\widetilde{X}_{f t}$ denotes total deflated expenditures on total inputs by firm $f$ at time $t$. We assume that this share does not vary across inputs and then solve for $\rho_{f h t}$ as follows. In order to eliminate unanticipated shocks and measurement error from the output data, we project the deflated export revenue, $q_{f h t}$, on all inputs, output and input tariffs, the output price, processing trade dummies, the interaction terms of processing trade dummies and input/output tariffs, region-industry-product dummies and time fixed effects to obtain the predicted values. We also project export quantity for each exported product $h$ and report related results in robustness checks.

We next compute a firm-product-specific term $\widehat{\varphi}_{f h t}: \widehat{\varphi}_{f h t}=E\left(q_{f h t}\right)-f\left(x_{f t}, \widehat{\beta}\right)$. From (13), this becomes:

$$
\begin{aligned}
\widehat{\varphi}_{f h t} & =\varphi_{f t}+A_{f h t}\left(\rho_{f h t} ; x_{f t} ; \widehat{\beta}\right) \\
& =\varphi_{f t}+\widehat{a}_{f t} \rho_{f h t}+\widehat{b}_{f t} \rho_{f h t}^{2}
\end{aligned}
$$

where the second equation follows from applying our translog production function. The terms $\widehat{a}_{f t}$, and $\widehat{b}_{f t}$ are functions of the estimated parameter vector $\widehat{\beta}$, which satisfy:

$$
\begin{aligned}
\widehat{a}_{f t} & =\widehat{\beta}_{l}+\widehat{\beta}_{m}+\widehat{\beta}_{k}+2\left(\widehat{\beta}_{l l} l_{f t}+\widehat{\beta}_{m m} m_{f t}+\widehat{\beta}_{k k} k_{f t}\right) \\
& +\widehat{\beta}_{l m}\left(l_{f t}+m_{f t}\right)+\widehat{\beta}_{l k}\left(l_{f t}+k_{f t}\right)+\widehat{\beta}_{m k}\left(m_{f t}+k_{f t}\right) \\
\widehat{b}_{f t} & =\widehat{\beta}_{l l}+\widehat{\beta}_{m m}+\widehat{\beta}_{k k}+\widehat{\beta}_{l m}+\widehat{\beta}_{l k}+\widehat{\beta}_{m k}
\end{aligned}
$$

we can construct $\widehat{\varphi}_{f h t}$ for each multi-product firm observation (firm-product-year triplet). For each year, we obtain the firm's productivity and input allocations, the $J+1$ unknowns

\footnotetext{
${ }^{18}$ We use 4-digit CIC industry level output deflators from Brandt, Van Biesebroeck and Zhang (2012) to deflate sales revenue.
} 
$\left(\varphi_{f t}, \rho_{f 1 t}, \ldots, \rho_{f J t}\right)$ by solving a system of $J+1$ equations:

$$
\begin{gathered}
\widehat{\varphi}_{f 1 t}=\varphi_{f t}+a_{f t} \rho_{f 1 t}+b_{f t} \rho_{f 1 t}^{2} \\
\ldots \ldots \\
\widehat{\varphi}_{f J t}=\varphi_{f t}+a_{f t} \rho_{f J t}+b_{f t} \rho_{f J t}^{2}
\end{gathered}
$$

and the equation that the sum of $\rho_{f h t}$ across product (and destination) for any firm $f$ at time $t$ equals the share of total export in the total sales of that firm. Here we modify the proportional assumption in De Loecker et al. (2014) due to the data restriction. ${ }^{19}$ We numerically solve this system for each firm in each year. ${ }^{20}$ We now have all the ingredients to compute markups and the implied marginal costs for the multi-product firms according to equation (11):

$$
\widehat{\mu}_{f h t}=\ln \left(\widehat{\theta}_{f h t}^{M} \frac{P_{f h t} Q_{f h t}}{\exp \left(\widehat{\rho}_{f h t}\right) P_{f t}^{M} V_{f t}^{M}}\right)
$$

where the product-specific output elasticity for materials $\widehat{\theta}_{f h t}^{M}$ is a function of the production function coefficients, expressed by equation (15); $P_{f h t} Q_{f h t}$ is the export value for product $h$, which is directly obtained from customs data; $\exp \left(\widehat{\rho}_{f h t}\right) P_{f t}^{M} V_{f t}^{M}$ denotes the materials allocated to produce the product $h$. The expression for the materials output elasticity for product $h$ at time $t$ is:

$$
\widehat{\theta}_{f h t}^{M}=\widehat{\beta}_{m}+2 \widehat{\beta}_{m m}\left(\widehat{\rho}_{f h t}+m_{f t}\right)+\widehat{\beta}_{l m}\left(\widehat{\rho}_{f h t}+l_{f t}\right)+\widehat{\beta}_{m k}\left(\widehat{\rho}_{f h t}+k_{f t}\right)
$$

Finally, marginal costs for the product $h$ at time $t$ are then recovered by subtracting the markup from the log price according to the following equation:

$$
\widehat{m c}_{f h t}=\ln \left(P_{f h t}\right)-\widehat{\mu}_{f h t}
$$

Our estimated markup are summarized for ordinary trade firms and processing trade firms in Table A.1 in Appendix. In all sectors, the average markup is higher than 1. The highest for ordinary trade firms being in Communication Equipment, Computers and Other Electronic Equipment (2-digit CIC industry code 40) with an average markup of 3.1, whereas the highest for processing trade firms are in Processing of Timber, Manufacture of Wood, Bamboo, Rattan, Palm, and Straw Products (2-digit CIC industry code

\footnotetext{
${ }^{19}$ See equation (29) in De Loecker et al. (2014) for the original proportional assumption.

${ }^{20}$ Similar as in De Loecker et al. (2014), we experiment with various starting values for the unknowns to solve this system of equations and find that conditional on converging to an inside solution (e.g., all the product's input shares are between 0 and the share of total export in the total sales of that firm, non-inclusive), the solution is unique. Out of the total sample of multi-product firm-year pairs, we dropped no more than 0.5 percent of all observations in the final sample due to corner solutions.
} 
20) with an average markup of 2.7 .

Figure 3: Input and Output Tariffs in China (2000-2006)

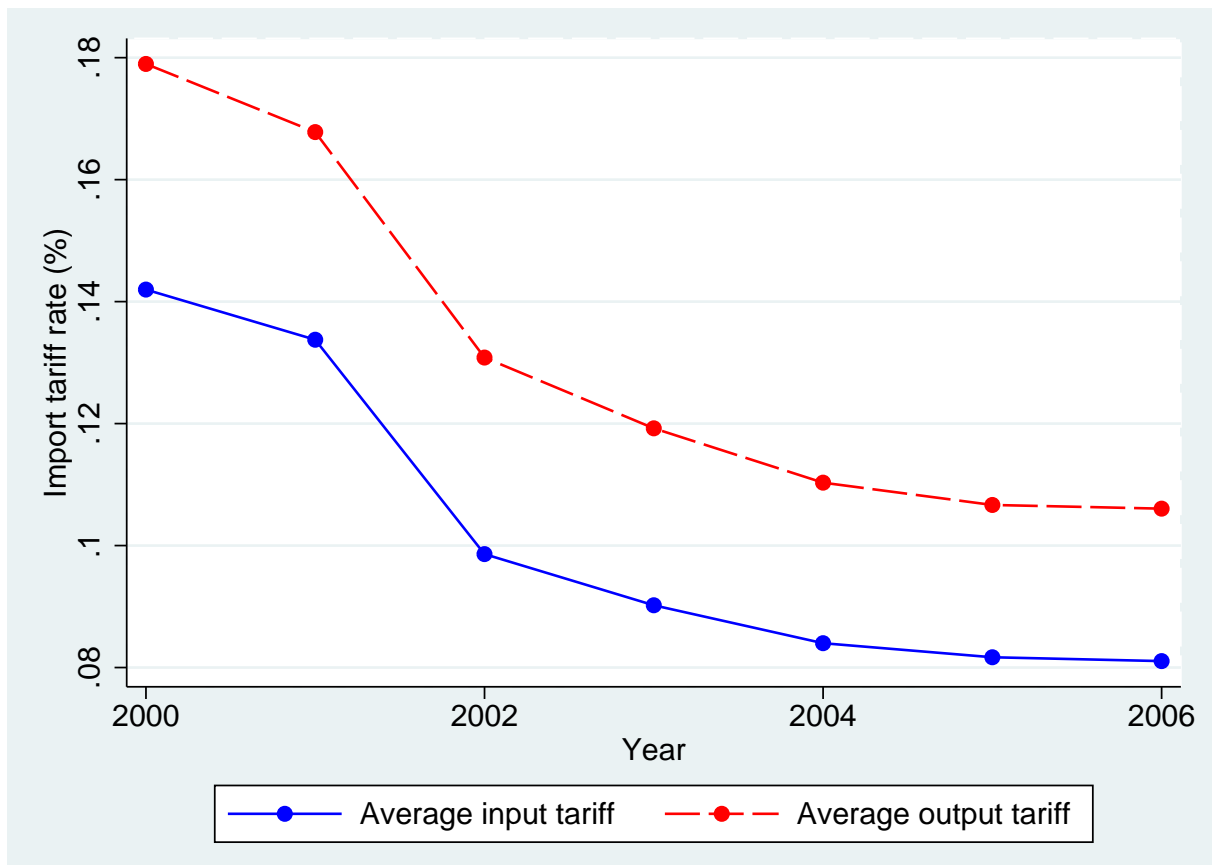

\subsection{Measure of input and output tariff}

To construct the tariffs, we first draw the tariff lines from the WTO and the trade analysis and information system (TRAINS). To be consistent with the Input-Output (IO) table of China that we will use later, we map the harmonized system (HS) 8-digit tariffs into the 5-digit IO code. Our 5-digit output tariff, then, is the simple average of the tariffs in the HS 8-digit codes within each 5-digit IO industry code.

To compute the input tariff, following Amiti and Konings (2007) we use an input cost weighted average of output tariffs where:

$$
\tau_{i t}^{\text {input }}=\sum_{k} a_{k i} \tau_{k t}^{\text {output }}
$$

where $\tau_{k t}^{\text {output }}$ is the tariff on industry $k$ at time $t$, and $a_{k i}$ is the weight of industry $k$ in the input cost of industry $i$. For instance, if industry $i$ incurs $80 \%$ of its costs in steel and $20 \%$ of its costs in rubber then steel tariffs receive a $80 \%$ weight in our calculation of input tariffs in industry $i$, while rubber tariffs receive a $20 \%$ weight.

Since our production data utilizes the CIC (Chinese Industrial Classification) 4-digit code, we then map the IO 5-digit input and output tariffs into the CIC 4-digit industry code. This procedure then yields a set of input and output tariffs at CIC 4-digit level. Our 
main results are based on this set of industry-level input and output tariffs. Nevertheless, we also report results using firm-level input tariffs in the robustness part (see Section 6.2) and our main results remain largely unchanged. Figure 3 presents the industry-level input and output tariffs in China during 2000-2006. It shows that there is a drastic drop of tariff rates since China joined WTO in 2001.

\section{Specifications and results}

In this section, we describe our econometric models and present our main estimation results. Note that our baseline specification refers to the sample of ordinary trading firms. We also use a placebo sample of export processing firms that were never subjected to import tariffs to test the ordinary trade results. We also test marginal cost and import dependence effects to confirm underlying mechanisms of our theoretical model.

\subsection{Trade liberalization effects on markup}

We now examine how markups have responded to tariff reductions during periods of trade liberalization in China.

Baseline regression.- Our model suggests that together with typical pro-competitive effects (of output tariffs), trade liberalization may affect firm markups via marginal cost effects of input tariffs. To test the overall effect of trade liberalization on markups, we adopt the following regression equation as our baseline specification:

$$
\mu_{f h t}=\kappa_{1} \text { input_tariff }_{i t}+\kappa_{2} \text { output_tariff }_{i t}+\boldsymbol{\kappa}_{3} \boldsymbol{E}_{f t}+\boldsymbol{\kappa}_{4} \boldsymbol{S}_{i t}+\delta_{t}+\delta_{s}+\delta_{f h}+\epsilon_{f h t}
$$

where $\mu_{f h t}$ denotes the estimated firm-product markup of HS6 product $h$ by firm $f$ in year $t$, and $i$ denotes a 4 -digit CIC industry. The vector of firm-level controls, $\boldsymbol{E}_{f t}$, is to account for the firm characteristics such as productivity, employment size, capital-labor ratio and average wage that potentially could impact markups. The vector of industry-

level controls, $\boldsymbol{S}_{i t}$, include industrial average wage (WAGE), capital intensity $(K L)$, and Herfindahl index $(H H I)$ that are computed at the 4-digit CIC industry each year to capture the endowment characteristics and the competition effect of the industry. We also control for the time fixed effect $\left(\delta_{t}\right)$, the 2-digit CIC sector fixed effect $\left(\delta_{s}\right)$, and the firm-product fixed effect $\left(\delta_{f h}\right)$ to account for all the characteristics that are timevarying, sector and firm-product related. As the variable of interest in equation (17) is the industry-level tariffs, we cluster error terms at the industry-year pair to address the potential correlation of errors within each industry over time. Our model predicts a negative coefficient on input tariffs for ordinary trade firms in the baseline regression, 
while no significant effects on markups for the placebo sample of the exporting processing firms that, by law, are not subject to any import duties, during trade liberalization. The results of the placebo test for processing trade will be reported separately in comparison with those for ordinary trade.

Table 1: Impact of Tariffs on Markups (Ordinary Trade)

\begin{tabular}{|c|c|c|c|c|c|c|}
\hline \multicolumn{7}{|c|}{ Dependent variable: Firm-product markup } \\
\hline & (1) & $(2)$ & $(3)$ & $(4)$ & $(5)$ & $(6)$ \\
\hline Input tariff & $\begin{array}{c}-4.393^{* *} \\
(1.797)\end{array}$ & $\begin{array}{c}-4.624^{* * *} \\
(1.676)\end{array}$ & $\begin{array}{c}-4.061^{* *} \\
(1.658)\end{array}$ & $\begin{array}{c}-3.714^{* *} \\
(1.687)\end{array}$ & $\begin{array}{c}-3.937^{* * *} \\
(1.481)\end{array}$ & $\begin{array}{c}-2.391^{*} \\
(1.382)\end{array}$ \\
\hline Output tariff & $\begin{array}{c}0.246 \\
(1.292)\end{array}$ & $\begin{array}{c}1.906 \\
(1.233)\end{array}$ & $\begin{array}{c}1.852 \\
(1.191)\end{array}$ & $\begin{array}{c}0.427 \\
(1.104)\end{array}$ & $\begin{array}{c}1.750 \\
(1.215)\end{array}$ & $\begin{array}{c}1.315 \\
(1.126)\end{array}$ \\
\hline $\log (\mathrm{TFP})$ & & & $\begin{array}{c}0.991^{* * *} \\
(0.081)\end{array}$ & & & $\begin{array}{c}1.030^{* * *} \\
(0.052)\end{array}$ \\
\hline $\log ($ Labor $)$ & & & $\begin{array}{l}-0.028 \\
(0.054)\end{array}$ & & & $\begin{array}{l}-0.039 \\
(0.041)\end{array}$ \\
\hline $\log$ (Capital/Labor) & & & $\begin{array}{c}0.034 \\
(0.041)\end{array}$ & & & $\begin{array}{c}0.003 \\
(0.024)\end{array}$ \\
\hline $\log$ (Wage) & & & $\begin{array}{c}0.011 \\
(0.042)\end{array}$ & & & $\begin{array}{c}0.010 \\
(0.024)\end{array}$ \\
\hline WAGE & & & $\begin{array}{l}-0.007 \\
(0.009)\end{array}$ & & & $\begin{array}{l}-0.009 \\
(0.011)\end{array}$ \\
\hline $\mathrm{KL}$ & & & $\begin{array}{l}-0.000 \\
(0.001)\end{array}$ & & & $\begin{array}{l}-0.000 \\
(0.001)\end{array}$ \\
\hline HHI & & & $\begin{array}{c}0.035 \\
(0.560)\end{array}$ & & & $\begin{array}{c}-0.201 \\
(0.680)\end{array}$ \\
\hline Year Fixed Effect & YES & YES & YES & YES & YES & YES \\
\hline Industry Fixed Effect & NO & YES & YES & NO & YES & YES \\
\hline Firm-Product Fixed Effect & YES & YES & YES & YES & YES & YES \\
\hline Observations & 604110 & 604110 & 603705 & 604110 & 604110 & 603705 \\
\hline R-squared & .739 & .742 & .743 & .727 & .728 & .730 \\
\hline
\end{tabular}

Notes: ${ }^{* * *} \mathrm{p}<0.01,{ }^{* *} \mathrm{p}<0.05,{ }^{*} \mathrm{p}<0.1$. Robust standard errors corrected for clustering at the industry-year level in parentheses. We only use ordinary trade observations in this Table. In specifications 4-6 we run regression weighted by the number of observations in the 2-digit CIC industry. The number of observations in columns 3 and 6 are less than the one in columns 1-2 and 4-5 due to the missing wage information for some firms in our sample.

Ordinary trade.-We first run our baseline regression as in equation (17) using ordinary trade observations. Table 1 reports significantly negative coefficients of input tariffs for all specifications: an input tariff decline of 1 percent is associated with a markup increase of approximately 4-5 percent in unweighted regressions of columns 1-3 and of 2-4 percent in weighted regressions of columns 4-6. In each of the three columns (columns 1-3 and 4-6), the first reports results without industry fixed effects and firm/industrylevel controls; the second reports results with industry fixed effects but without other 
Table 2: Impact of Tariffs on Markups (Processing Trade)

Dependent variable: Firm-product markup

(1) (2)

(3) (4) (5)

(6)

\begin{tabular}{|c|c|c|c|c|c|c|}
\hline Input tariff & $\begin{array}{l}-0.630 \\
(1.170)\end{array}$ & $\begin{array}{l}-0.696 \\
(1.300)\end{array}$ & $\begin{array}{l}-0.527 \\
(1.414)\end{array}$ & $\begin{array}{l}-0.384 \\
(1.440)\end{array}$ & $\begin{array}{l}-0.293 \\
(1.489)\end{array}$ & $\begin{array}{c}0.121 \\
(1.533)\end{array}$ \\
\hline Output tariff & $\begin{array}{l}-0.674 \\
(0.994)\end{array}$ & $\begin{array}{c}0.276 \\
(1.098)\end{array}$ & $\begin{array}{c}0.248 \\
(1.067)\end{array}$ & $\begin{array}{l}-0.937 \\
(0.968)\end{array}$ & $\begin{array}{c}0.179 \\
(1.090)\end{array}$ & $\begin{array}{c}0.004 \\
(1.023)\end{array}$ \\
\hline $\log (\mathrm{TFP})$ & & & $\begin{array}{c}0.960 * * * \\
(0.041)\end{array}$ & & & $\begin{array}{c}1.008^{* * *} \\
(0.048)\end{array}$ \\
\hline $\log$ (Labor) & & & $\begin{array}{l}-0.007 \\
(0.042)\end{array}$ & & & $\begin{array}{l}-0.010 \\
(0.040)\end{array}$ \\
\hline $\log ($ Capital/Labor $)$ & & & $\begin{array}{c}0.045 \\
(0.041)\end{array}$ & & & $\begin{array}{c}0.047 \\
(0.034)\end{array}$ \\
\hline $\log$ (Wage) & & & $\begin{array}{c}0.003 \\
(0.019)\end{array}$ & & & $\begin{array}{l}-0.009 \\
(0.022)\end{array}$ \\
\hline WAGE & & & $\begin{array}{c}0.002 \\
(0.005)\end{array}$ & & & $\begin{array}{c}0.002 \\
(0.006)\end{array}$ \\
\hline $\mathrm{KL}$ & & & $\begin{array}{l}-0.000 \\
(0.000)\end{array}$ & & & $\begin{array}{l}-0.000 \\
(0.001)\end{array}$ \\
\hline HHI & & & $\begin{array}{c}0.570 \\
(0.442)\end{array}$ & & & $\begin{array}{c}0.626 \\
(0.553)\end{array}$ \\
\hline Year Fixed Effect & YES & YES & YES & YES & YES & YES \\
\hline Industry Fixed Effect & NO & YES & YES & NO & YES & YES \\
\hline Firm-Product Fixed Effect & YES & YES & YES & YES & YES & YES \\
\hline Observations & 182238 & 182238 & 182076 & 182238 & 182238 & 182076 \\
\hline R-squared & .685 & .686 & .688 & .707 & .707 & .710 \\
\hline \multicolumn{7}{|c|}{$\begin{array}{l}\text { Notes: }{ }^{* * *} \mathrm{p}<0.01,{ }^{* *} \mathrm{p}<0.05, * \mathrm{p}<0.1 \text {. Robust standard errors corrected for } \\
\text { clustering at the industry-year level in parentheses. We only use processing trade } \\
\text { observations in this Table. In specifications } 4-6 \text { we run regression weighted by the } \\
\text { number of observations in the } 2 \text {-digit CIC industry. The number of observations in } \\
\text { columns } 3 \text { and } 6 \text { are less than the one in columns } 1-2 \text { and } 4-5 \text { due to the missing wage } \\
\text { information for some firms in our sample. }\end{array}$} \\
\hline
\end{tabular}

firm/industry-level controls; and the third presents results with all fixed effects when controlling for firm/industry-level controls. The magnitude of input tariff effects on markups is very stable across all specifications.

We run weighted regressions, as our dependent variable is the estimated markup, which relies on production function estimations. However, the production function estimation is conducted using a two-digit CIC sector, and we are more confident of estimates that are based on enough sector observations. Following De Loecker et al. (2014), we weigh previous regressions based on the number of observations for each two-digit CIC sector production function estimation reported. In columns 4-6 of Table 1, coefficients of interest are of similar sign and magnitude, suggesting that our findings are robust to 
these specifications.

Output tariff effects on markups shown in Table 1 are positive but insignificant, complementing pro-competitive effects of trade liberalization described in the literature: lower output tariffs during the trade liberalization intensify competition and thus reduce firms' market power and markups. Note that the coefficients on TFP are also significantly positive (see columns 3 and 6), indicating that more productive firms charge higher markups and providing supportive evidence to Lemma 1.

Processing trade.-As firms that conduct processing trade are not subject to tariffs, we expect the impact of tariffs to be absent among those firms. Table 2 confirms our belief: in all specifications that we employ, none suggests that import tariffs (both input and output tariffs) significantly impact firms' markups.

\subsection{The underlying mechanisms}

Import dependence.- - Our model studies the markup adjustment of an incumbent importing/exporting firm that imports intermediate inputs. The model predicts that a tariff reduction leads to an increase in markup. This effect would be more profound for firms with higher import intensity. This underlying mechanism is described as follows.

During trade liberalization, a reduction in import tariff leads to a fall in the imported input price index $P_{M}$ and, hence, a reduction in the cost-reduction factor $B$. When $\tau_{h}=\tau$ for all imported input $h$, the effect of a reduction in import tariff on the cost-reduction factor satisfies:

$$
\Delta \ln B \equiv \frac{\left(P_{M}\right)^{1-\varsigma}}{\left(P_{Z}\right)^{1-\varsigma}+\left(P_{M}\right)^{1-\varsigma}} d \ln \tau
$$

where $\frac{\left(P_{M}\right)^{1-\varsigma}}{\left(P_{Z}\right)^{1-\varsigma}+\left(P_{M}\right)^{1-\varsigma}}$ equals the expenditure share on imported intermediate goods in the total expenditure on intermediate inputs. For the firm with higher import share, a reduction in import tariff leads to a larger decline in $\ln B$ and hence a larger decline in $\ln c$ where $c$ is marginal cost (see equation (6)). ${ }^{21}$ It in turn increases the efficiency of the firm, $v$, more and hence leads to a higher increase in markup.

Therefore, it is natural to expect that an importing firm would enjoy more benefit of trade liberalization than a non-importing firm, and a firm with higher import intensity would enjoy more benefit of tariff reductions than a firm with lower import intensity,

\footnotetext{
${ }^{21}$ The effect of a reduction in import tariff on marginal cost satisfies: $\Delta \ln c \equiv \eta \Delta \ln B \equiv$ $\eta \frac{\left(P_{M}\right)^{1-\varsigma}}{\left(P_{Z}\right)^{1-\varsigma}+\left(P_{M}\right)^{1-\varsigma}} d \ln \tau$
} 
given all other conditions equal:

$$
\begin{aligned}
\mu_{f h t} & =\kappa_{1} \text { input_tariff }_{i t}+\kappa_{2} \text { output_tariff }_{i t}+\kappa_{5} \text { import_status }_{f t} \\
& +\kappa_{\text {im }} \text { input_tariff }_{i t} \text { import_status }_{f t}+\boldsymbol{\kappa}_{3} \boldsymbol{E}_{f t}+\boldsymbol{\kappa}_{4} \boldsymbol{S}_{i t}+\delta_{t}+\delta_{s}+\delta_{f h}+\epsilon_{f h t}
\end{aligned}
$$

where the firm-specific import_status could be a dummy variable, Importing firm, which is equal to one if the firm is importing and zero otherwise, or a continuous variable, Import share, i.e., import intensity of the firm, computed by the ratio of the cost of imported inputs to total cost of intermediate inputs of the firm. We expect the coefficient on import_status, $\kappa_{5}$, to be positive in equation (18), and the coefficient on the interaction term, $\kappa_{i m}$, to be negative. This means that a firm that conducts importing more intensively would be more affected by the input tariff reductions and enjoy a larger increase of markup, ceteris paribus. As we expect that the effect of input tariffs depend on the extent to which the firm uses imported inputs, we run the regression with the import status of the firm as specified in equation (18) and report results in Table 3.

In Table 3, we can compare the results for ordinary trade in columns 1-4 and for processing trade in columns 5-8. Columns 1-2 and 5-6 use unweighted regressions, while columns 3-4 and 7-8 adopt weighted regressions. In the weighted regressions for ordinary trade, for an importing firm, the impact of input tariffs on markup is higher by 133 percent compared with a non-importing firm in column 3. More precisely, a 10 percent increase in the import share of the firm (compared with a non-importing firm) raises the impact of input tariffs on markups by 19 percent in column 2 for unweighted regression and by 45 percent in column 4 for weighted regression. The coefficient on the interaction term, $\kappa_{i m}$, in column 1 also presents the expected sign with approximately $20 \%$ significance level. These results suggest that firms with higher import intensity adjust markup more during trade liberalization.

Our results are also consistent with Amiti, Itskhoki and Konings $(A E R, 2014)$ in which they show that import intensity and market share are positively correlated. Moreover, firms with larger market shares (and therefore more market power and higher markups) adjust their markups more in response to trade liberalization. Therefore, our results that firms with higher import intensity adjust markups more in response to tariff reductions complement Amiti, Itskhoki and Konings (2014). Note that in the placebo tests with the sample of processing trade in columns 5-8 of Table 3, we do not observe the expected effect of input tariff as well as the interaction effect with import status of the firm.

Marginal cost channel.-As our model predicts that the trade liberalization via the input tariff reductions would lead to the fall of marginal costs, we test the impact of input and output tariff reductions on marginal costs using the following specification where we 
Table 3: The Effect of Tariffs on Markups by Import Dependence

Dependent variable: Firm-product markup

$\underline{\text { unweighted ordinary } \quad \text { weighted ordinary } \quad \text { unweighted processing weighted processing }}$
(1)
(2)
(3)
$(4)$
(5) (6)
(7)
(8)

\begin{tabular}{|c|c|c|c|c|c|c|c|c|}
\hline Input tariff & $\begin{array}{l}-3.076 \\
(1.918)\end{array}$ & $\begin{array}{l}-3.264^{*} \\
(1.713)\end{array}$ & $\begin{array}{l}-1.119 \\
(1.513)\end{array}$ & $\begin{array}{l}-1.664 \\
(1.394)\end{array}$ & $\begin{array}{l}-1.087 \\
(1.871)\end{array}$ & $\begin{array}{c}-0.881 \\
(1.556)\end{array}$ & $\begin{array}{c}0.567 \\
(1.975)\end{array}$ & $\begin{array}{l}-0.206 \\
(1.560)\end{array}$ \\
\hline Output tariff & $\begin{array}{c}1.810 \\
(1.192)\end{array}$ & $\begin{array}{c}1.839 \\
(1.182)\end{array}$ & $\begin{array}{c}1.257 \\
(1.120)\end{array}$ & $\begin{array}{c}1.377 \\
(1.127)\end{array}$ & $\begin{array}{c}0.249 \\
(1.067)\end{array}$ & $\begin{array}{c}0.227 \\
(1.069)\end{array}$ & $\begin{array}{c}0.002 \\
(1.022)\end{array}$ & $\begin{array}{l}-0.022 \\
(1.033)\end{array}$ \\
\hline Input tariff $\times$ Importing firm & $\begin{array}{l}-1.167 \\
(0.863)\end{array}$ & & $\begin{array}{c}-1.486^{* * *} \\
(0.567)\end{array}$ & & $\begin{array}{c}0.558 \\
(1.289)\end{array}$ & & $\begin{array}{l}-0.439 \\
(1.448)\end{array}$ & \\
\hline Importing firm & $\begin{array}{c}0.149 \\
(0.103)\end{array}$ & & $\begin{array}{c}0.162^{* *} \\
(0.063)\end{array}$ & & $\begin{array}{l}-0.050 \\
(0.120)\end{array}$ & & $\begin{array}{c}0.052 \\
(0.137)\end{array}$ & \\
\hline Input tariff $\times$ Import share & & $\begin{array}{l}-6.352^{*} \\
(3.523)\end{array}$ & & $\begin{array}{c}-7.437^{* * *} \\
(2.740)\end{array}$ & & $\begin{array}{c}1.021 \\
(1.001)\end{array}$ & & $\begin{array}{c}0.951 \\
(0.807)\end{array}$ \\
\hline Import share & & $\begin{array}{l}1.209^{* *} \\
(0.536)\end{array}$ & & $\begin{array}{c}1.165^{* *} \\
(0.461)\end{array}$ & & $\begin{array}{l}-0.182 \\
(0.172)\end{array}$ & & $\begin{array}{l}-0.183 \\
(0.144)\end{array}$ \\
\hline $\log (\mathrm{TFP})$ & $\begin{array}{c}0.990^{* * * *} \\
(0.081)\end{array}$ & $\begin{array}{c}0.961^{* * *} \\
(0.083)\end{array}$ & $\begin{array}{c}1.028^{* * *} \\
(0.052)\end{array}$ & $\begin{array}{c}1.005^{* * *} \\
(0.055)\end{array}$ & $\begin{array}{c}0.960^{* * *} \\
(0.041)\end{array}$ & $\begin{array}{c}0.971^{* * *} \\
(0.040)\end{array}$ & $\begin{array}{c}1.008^{* * *} \\
(0.048)\end{array}$ & $\begin{array}{c}1.019^{* * *} \\
(0.050)\end{array}$ \\
\hline Other Firm-level Controls & YES & YES & YES & YES & YES & YES & YES & YES \\
\hline Industry-level Controls & YES & YES & YES & YES & YES & YES & YES & YES \\
\hline Year Fixed Effect & YES & YES & YES & YES & YES & YES & YES & YES \\
\hline Industry Fixed Effect & YES & YES & YES & YES & YES & YES & YES & YES \\
\hline Firm-Product Fixed Effect & YES & YES & YES & YES & YES & YES & YES & YES \\
\hline Observations & 603705 & 603705 & 603705 & 603705 & 182076 & 182076 & 182076 & 182076 \\
\hline R-squared & .743 & .743 & .730 & .730 & .688 & .688 & .710 & .710 \\
\hline $\begin{array}{l}\text { Notes: }{ }^{* * *} \mathrm{p}<0.01,{ }^{* *} \mathrm{p}< \\
\text { parentheses. Specifications } 1- \\
5-6 \text { we run unweighted regress } \\
\text { in the 2-digit CIC industry. } \\
\text { average wage; industry-level }\end{array}$ & $\begin{array}{l}05,{ }^{*} \mathrm{p}< \\
\text { refer to o } \\
\text { ons, and } \mathrm{i} \\
\text { her firm-l } \\
\text { ntrols inc }\end{array}$ & $\begin{array}{l}\text { 1. Robus } \\
\text { nary trac } \\
\text { columns } \\
\text { el control } \\
\text { le industı }\end{array}$ & $\begin{array}{l}\text { tandard } \\
\text { and spec } \\
\text { and } 7-8 \\
\text { nclude fil }\end{array}$ & run reg & $\begin{array}{l}\mathrm{d} \text { for clus } \\
\text { efer to pr } \\
\text { ion weigh } \\
\text { red by en }\end{array}$ & $\begin{array}{l}\text { ing at the } \\
\text { essing trac } \\
\text { l by the } r \\
\text { oyment), } \\
\text { Herfindal }\end{array}$ & $\begin{array}{l}\text { dustry-y } \\
\text { In colun } \\
\text { aber of o } \\
\text { ital-labo } \\
\text { ndex at }\end{array}$ & $\begin{array}{l}\text { r level in } \\
\text { s } 1-2 \text { and } \\
\text { ervations } \\
\text { ratio and } \\
\text { digit CIC }\end{array}$ \\
\hline
\end{tabular}

expect the coefficient on input_tariff to be significantly positive:

$m c_{f h t}=\kappa_{1}$ input_tariff $_{i t}+\kappa_{2}$ output_tariff ${ }_{i t}+\boldsymbol{\kappa}_{3} \boldsymbol{E}_{f t}+\boldsymbol{\kappa}_{4} \boldsymbol{S}_{i t}+\delta_{t}+\delta_{s}+\delta_{f h}+\epsilon_{f h t}$.

To further present the underlying mechanism via marginal cost, we augment our baseline regression (17) by controlling for the marginal cost in the right-hand side:

$\mu_{f h t}=\kappa_{1}$ input_tariff $_{i t}+\kappa_{2}$ output_tariff $_{i t}+\kappa_{m c} m c_{f h t}+\boldsymbol{\kappa}_{3} \boldsymbol{E}_{f t}+\boldsymbol{\kappa}_{4} \boldsymbol{S}_{i t}+\delta_{t}+\delta_{s}+\delta_{f h}+\epsilon_{f h t}$.

If the marginal cost is the main channel to explain the impact of input tariffs on markups, we would expect most (or at least the major part) of the impact of input tariffs on markups dilutes once we control for the marginal costs. Therefore, the coefficient on marginal 
cost, $\kappa_{m c}$, is of our interest and is expected to be significantly negative, indicating that a reduction in the marginal cost leads to a rise in the markup. More importantly, we expect that the magnitude of the coefficient on input tariff in regression equation (20) would be insignificant statistically or at least economically. The results of testing the marginal cost effects are presented in Table 4.

Table 4: The Effect of Tariffs on Markups: The Mechanism of Marginal Costs

\begin{tabular}{|c|c|c|c|c|c|c|c|c|}
\hline & \multicolumn{4}{|c|}{ Sample of Ordinary Trade } & \multicolumn{4}{|c|}{ Sample of Processing Trade } \\
\hline & $(1)$ & $(2)$ & $(3)$ & $(4)$ & (5) & $(6)$ & $(7)$ & $(8)$ \\
\hline & \multicolumn{2}{|c|}{ marginal cost } & \multicolumn{2}{|c|}{ markup } & \multicolumn{2}{|c|}{ marginal cost } & \multicolumn{2}{|c|}{ markup } \\
\hline Input tariff & $\begin{array}{l}3.933^{* *} \\
(1.741)\end{array}$ & $\begin{array}{l}3.450^{*} \\
(1.805)\end{array}$ & $\begin{array}{l}-0.816 \\
(0.553)\end{array}$ & $\begin{array}{l}-0.720 \\
(0.511)\end{array}$ & $\begin{array}{c}0.848 \\
(1.515)\end{array}$ & $\begin{array}{c}0.654 \\
(1.654)\end{array}$ & $\begin{array}{c}0.125 \\
(0.534)\end{array}$ & $\begin{array}{c}0.106 \\
(0.514)\end{array}$ \\
\hline Output tariff & $\begin{array}{l}-1.893 \\
(1.258)\end{array}$ & $\begin{array}{l}-1.869 \\
(1.238)\end{array}$ & $\begin{array}{c}0.073 \\
(0.229)\end{array}$ & $\begin{array}{c}0.042 \\
(0.216)\end{array}$ & $\begin{array}{l}-0.237 \\
(1.105)\end{array}$ & $\begin{array}{l}-0.213 \\
(1.079)\end{array}$ & $\begin{array}{c}0.046 \\
(0.249)\end{array}$ & $\begin{array}{c}0.042 \\
(0.248)\end{array}$ \\
\hline marginal cost & & & $\begin{array}{c}-0.969^{* * *} \\
(0.009)\end{array}$ & $\begin{array}{c}-0.968^{* * *} \\
(0.009)\end{array}$ & & & $\begin{array}{c}-0.969^{* * *} \\
(0.009)\end{array}$ & $\begin{array}{c}-0.968^{* * *} \\
(0.009)\end{array}$ \\
\hline $\log (\mathrm{TFP})$ & & $\begin{array}{c}-0.963^{* * *} \\
(0.085)\end{array}$ & & $\begin{array}{c}0.058^{* * *} \\
(0.015)\end{array}$ & & $\begin{array}{c}-0.913^{* * *} \\
(0.047)\end{array}$ & & $\begin{array}{c}0.076^{* * *} \\
(0.019)\end{array}$ \\
\hline Other Firm-level Controls & $\mathrm{NO}$ & YES & $\mathrm{NO}$ & YES & $\mathrm{NO}$ & YES & $\mathrm{NO}$ & YES \\
\hline Industry-level Controls & $\mathrm{NO}$ & YES & NO & YES & $\mathrm{NO}$ & YES & $\mathrm{NO}$ & YES \\
\hline Year Fixed Effect & YES & YES & YES & YES & YES & YES & YES & YES \\
\hline Industry Fixed Effect & YES & YES & YES & YES & YES & YES & YES & YES \\
\hline Firm-Product Fixed Effect & YES & YES & YES & YES & YES & YES & YES & YES \\
\hline Observations & 604110 & 603705 & 604110 & 603705 & 182238 & 182076 & 182238 & 182076 \\
\hline R-squared & .799 & .800 & .991 & .991 & .814 & .815 & .989 & .989 \\
\hline
\end{tabular}

Notes: ${ }^{* * *} \mathrm{p}<0.01,{ }^{* *} \mathrm{p}<0.05,{ }^{*} \mathrm{p}<0.1$. Robust standard errors corrected for clustering at the industry-year level in parentheses. Specifications 1-4 refer to ordinary trade, and specifications 5-8 refer to processing trade. In columns 1-2 and 5-6 the dependent variables are firm-product level marginal costs; in columns 3-4 and 7-8 the dependent variables are firm-product level markups. Other firm-level controls include firm size (measured by employment), capital-labor ratio and average wage; industry-level controls include industry average wage, capital intensity, and Herfindahl index at 4-digit CIC industry level each year. The number of observations in even columns are less than the one in odd columns due to the missing wage information for some firms in our sample.

The results in Table 4 are consistent with our expectation. In columns 1-4 of Table 4 , we present the results of ordinary trade sample. When we regress marginal costs on tariffs as specified in equation (19) in columns 1-2, the coefficients on input tariffs are significantly positive, indicating that a reduction in input tariffs would leads to the fall in marginal costs: cutting the input tariff by 1 percent will lower the marginal cost by approximately 4 percent. This effect only applies to ordinary trade (see columns 1-2) but the input tariff reduction has no significant impact on processing firms' marginal costs in columns 5-6.

In Table 4, firm productivity presents significantly negative coefficients in columns 2 and 6, suggesting a negative correlation between firm productivity and marginal costs: a more productive firm features lower marginal costs. Note that when we put marginal 
costs in the right-hand side of the baseline regression as in equation (20), the coefficients on marginal costs are significantly negative, while now the effect of input tariff becomes insignificant in columns 3 and 4 . This provides the supportive evidence to our modeling strategy that the main effect of input tariffs on markups goes through the marginal cost channel. This also confirms Lemma 1 that more efficient firms (i.e., firms associated with lower marginal costs) charge higher markups. More importantly, the marginal cost effect works for both ordinary trade in columns 3-4 and processing trade in columns 7-8: in columns 7 and 8 we also see significantly negative coefficients on marginal costs when we run regressions with markups as dependent variable. This suggests that for both types of firms the adjustment of markups is mainly driven by the change in marginal costs, but clearly the impact of tariffs has no impacts on processing trade (see column 5-8).

\subsection{Difference estimator}

All the aforementioned estimations have been on levels with firm-product, industry and year fixed effects (see equation (17)). Now we experiment with alternative econometric estimation approaches using difference estimator with one-year, three-year, or five-year difference, and continue to control for the firm-level and industry-level characteristics and year fixed effects.

The results of difference estimation are reported in Table 5. We adopt first-difference (FD) estimator and long-difference estimator to estimate the impact of tariff changes on markup adjustment. The advantage of the difference approach is that it removes the latent heterogeneity from the model after the fixed-effects have been differenced out and therefore it is useful in addressing the problem of omitted variables in the panel data. Our previous results still hold when we employ the difference estimator with oneyear, three-year, and five-year difference. In the sample of ordinary trade, the change in input tariffs negatively impacts the markup adjustment: a 1 percent reduction in the input tariff would lead to a 6 percent increase in markups in one year. This significantly negative relationship between tariff changes and markup adjustment still holds when we use different periods in differences (see columns 3 and 4). Again, the impact of input tariff does not apply to the processing trade sample.

\subsection{Endogeneity}

Now we turn to the issue of the potential endogeneity of tariffs. According to Amiti and Konings (2007), in a firm fixed-effects model it is unclear whether there is in fact a serious endogeneity issue. In our baseline regressions we already include firm-product and industry fixed effects, and it is also arguable that tariff reductions are exogenous 
Table 5: The Effect of Tariffs on Markups: First-Difference and Long-Difference

\begin{tabular}{|c|c|c|c|c|c|c|c|c|}
\hline \multicolumn{9}{|c|}{$\begin{array}{l}\text { Dependent variable: } \Delta \text { (Firm-product markup) } \\
\text { Sample of Ordinary Trade }\end{array}$} \\
\hline & $(1)$ & $(2)$ & $(3)$ & $(4)$ & $(5)$ & $(6)$ & $(7)$ & $(8)$ \\
\hline & 1-year & 1-year & 3-year & 5-year & 1-year & 1-year & 3-year & 5-year \\
\hline$\Delta$ Input tariff & $\begin{array}{c}-6.034^{* *} \\
(2.589)\end{array}$ & $\begin{array}{c}-6.404^{* *} \\
(2.630)\end{array}$ & $\begin{array}{c}-3.372^{*} \\
(1.986)\end{array}$ & $\begin{array}{c}-7.369^{* *} \\
(3.453)\end{array}$ & $\begin{array}{l}-2.587 \\
(1.853)\end{array}$ & $\begin{array}{l}-2.724 \\
(1.811)\end{array}$ & $\begin{array}{l}-1.189 \\
(1.329)\end{array}$ & $\begin{array}{l}-1.124 \\
(2.016)\end{array}$ \\
\hline$\Delta$ Output tariff & $\begin{array}{c}2.147 \\
(1.396)\end{array}$ & $\begin{array}{c}2.246 \\
(1.435)\end{array}$ & $\begin{array}{l}-1.398 \\
(1.189)\end{array}$ & $\begin{array}{c}3.554 \\
(2.255)\end{array}$ & $\begin{array}{l}1.250^{* *} \\
(0.598)\end{array}$ & $\begin{array}{c}1.425^{* * *} \\
(0.540)\end{array}$ & $\begin{array}{c}0.638 \\
(0.948)\end{array}$ & $\begin{array}{l}-2.599 \\
(1.680)\end{array}$ \\
\hline$\Delta \log (\mathrm{TFP})$ & & $\begin{array}{c}1.006^{* * *} \\
(0.071)\end{array}$ & $\begin{array}{c}0.098 \\
(0.131)\end{array}$ & $\begin{array}{c}0.189 \\
(0.131)\end{array}$ & & $\begin{array}{c}0.974^{* * *} \\
(0.032)\end{array}$ & $\begin{array}{c}0.137^{* *} \\
(0.056)\end{array}$ & $\begin{array}{l}0.190^{*} \\
(0.103)\end{array}$ \\
\hline Changes in Other Firm-level Controls & NO & YES & YES & YES & NO & YES & YES & YES \\
\hline Industry-level Controls & NO & YES & YES & YES & NO & YES & YES & YES \\
\hline Year Fixed Effect & YES & YES & YES & YES & YES & YES & YES & YES \\
\hline Observations & 188832 & 188653 & 54873 & 13619 & 65954 & 65851 & 22452 & 6860 \\
\hline R-squared & .0001 & .004 & .001 & .002 & .0002 & .007 & .003 & .005 \\
\hline
\end{tabular}

Notes: ${ }^{* * *} \mathrm{p}<0.01,{ }^{* *} \mathrm{p}<0.05,{ }^{*} \mathrm{p}<0.1$. Robust standard errors corrected for clustering at the industry-year level in parentheses. Specifications 1-4 refer to ordinary trade, and specifications 5-8 refer to processing trade. In columns 1-2 and 5-6 we use one-year difference; in columns 3 and 7 we adopt three-year difference; in columns 4 and 8 we use five-year difference. Changes in other firm-level controls include the changes in firm size (measured by employment), capital-labor ratio and average wage; industry-level controls include industry average wage, capital intensity, and Herfindahl index at 4-digit CIC industry level. The number of observations in columns 2 and 6 are less than the one in columns 1 and 5 due to the missing wage information for some firms in our sample.

from an individual firm's perspective. Nevertheless, for the sake of completeness now we relax the assumption that the trade liberalization in China during the period 2000-2006 is exogenous, which invalidates our identification strategy. Suppose one could argue that tariff levels are set subject to the lobby effort in China. If the political pressure is only industry specific but time invariant then our control for the industry fixed effect alleviates this concern. When the factors are time variant, we rely on the instrumental variable estimation by instrumenting for input tariffs and output tariffs in Table 6. Similar as in Amiti and Konings (2007), all of the specifications in Table 6 are for the five-year difference model, as it is easier to find instruments for changes in tariffs than for levels.

The usual instrument for tariff changes is the level of past tariffs (Goldberg and Pavcnik, 2005). Time-invariant or initial industry-level characteristics are also suggested to be used as instruments in a difference model (Trefler, 2004). Following Amiti and Davis (2012), we use the initial tariffs and the proportion of skilled labor in total employment (skill intensity) as the full set of our instruments. As China entered the WTO in 2001 and started to reduce its tariffs significantly since then, we select the input and output tariff levels in the initial year 2000 into our simple set of instruments. Since the proportion of skilled labor is only available in 2004, we will have to make the assumption that this proportion does not change overtime (practically the industries have a Cobb-Douglas 
Table 6: The Effect of Tariffs on Markups: Instrumental Variable Estimation

\begin{tabular}{|c|c|c|c|c|c|c|c|c|}
\hline \multicolumn{9}{|c|}{ Dependent variable: $\Delta$ (Firm-product markup $)$} \\
\hline & $(1)$ & $(2)$ & $(3)$ & $(4)$ & $(5)$ & $(6)$ & $(7)$ & $(8)$ \\
\hline$\Delta$ Input tariff & $\begin{array}{l}-5.695^{*} \\
(3.002)\end{array}$ & $\begin{array}{c}-5.929^{* *} \\
(3.011)\end{array}$ & $\begin{array}{c}-7.347^{* *} \\
(3.064)\end{array}$ & $\begin{array}{c}-6.451^{* *} \\
(2.894)\end{array}$ & $\begin{array}{c}1.493 \\
(2.853)\end{array}$ & $\begin{array}{c}1.596 \\
(2.741)\end{array}$ & $\begin{array}{c}2.174 \\
(2.820)\end{array}$ & $\begin{array}{c}1.552 \\
(2.663)\end{array}$ \\
\hline$\Delta$ Output tariff & $\begin{array}{c}1.660 \\
(2.604)\end{array}$ & $\begin{array}{c}1.744 \\
(2.616)\end{array}$ & $\begin{array}{c}3.397 \\
(2.545)\end{array}$ & $\begin{array}{c}2.142 \\
(2.510)\end{array}$ & $\begin{array}{c}2.178 \\
(2.571)\end{array}$ & $\begin{array}{c}1.887 \\
(2.604)\end{array}$ & $\begin{array}{c}0.780 \\
(2.607)\end{array}$ & $\begin{array}{c}1.850 \\
(2.600)\end{array}$ \\
\hline Changes in Firm-level Controls & NO & YES & YES & YES & $\mathrm{NO}$ & YES & YES & YES \\
\hline Year Fixed Effect & YES & YES & YES & YES & YES & YES & YES & YES \\
\hline Set of Instruments & simple1 & simple1 & full & simple2 & simple1 & simple1 & full & simple2 \\
\hline No. of Excluded Instruments & 2 & 2 & 3 & 2 & 2 & 2 & 3 & 2 \\
\hline \multicolumn{9}{|l|}{ Ho: coefficient on $\Delta$ (Input tariff) equals 0} \\
\hline Partial R-squared & .824 & .824 & .825 & .818 & .755 & .754 & .756 & .746 \\
\hline F-stat & 22058 & 21999 & 14931 & 20959 & 9009 & 8777 & 5684 & 8468 \\
\hline \multicolumn{9}{|l|}{ Ho: coefficient on $\Delta$ (Output tariff) equals 0} \\
\hline Partial R-squared & .524 & .524 & .541 & .543 & .421 & .419 & .426 & .441 \\
\hline F-stat & 5521 & 5458 & 4183 & 6024 & 1417 & 1374 & 960 & 1458 \\
\hline Kleibergen-Paap rk LM $\chi^{2}(1)$ statistic ${ }^{\llbracket}$ & $1225.851^{\dagger}$ & $1207.371^{\dagger}$ & $1247.252^{\dagger}$ & $1225.673^{\dagger}$ & $537.282^{\dagger}$ & $509.680^{\dagger}$ & $509.706^{\dagger}$ & 514.674 \\
\hline Weak Instrument (F statistic) & $2459.301^{\dagger}$ & $2455.435^{\dagger}$ & $1795.236^{\dagger}$ & $2717.095^{\dagger}$ & $678.749^{\dagger}$ & $654.229^{\dagger}$ & $444.301^{\dagger}$ & $689.868^{+}$ \\
\hline Hansen $J$ statistic ( $p$-value) & - & - & .237 & - & - & - & .049 & - \\
\hline Observations & 13650 & 13619 & 13619 & 13619 & 6866 & 6860 & 6860 & 6860 \\
\hline \multicolumn{9}{|c|}{$\begin{array}{l}\left.\text { Notes: }{ }^{* *} \mathrm{p}<0.01,{ }^{* *} \mathrm{p}<0.05,{ }^{*} \mathrm{p}<0.1 .{ }^{\dagger} \text { indicates significance at the } 0.01 \text { percent level (p-value }<0.0001\right) \text {. Robust standard } \\
\text { errors in parentheses. Specifications } 1-4 \text { refer to ordinary trade, and specifications } 5-8 \text { refer to processing trade. In columns } 1-2 \\
\text { and } 5-6 \text { we use input tariff and output tariff levels in initial year } 2000 \text { as instruments (the simple set } 1 \text { of instruments); in columns } \\
3 \text { and } 7 \text { we further add skill intensity in } 2004 \text { to the previous set of instruments (the full set of instruments); in columns } 4 \text { and } \\
8 \text { we adopt the previous-year input and output tariff levels as instruments (the simple set } 2 \text { of instruments). }{ }^{\uparrow} \text { : in specifications } \\
3 \text { and } 7 \text { it would be Kleibergen-Paap rk LM } \chi^{2}(2) \text { statistic. Changes in firm-level controls include the changes in TFP, firm size } \\
\text { (measured by employment), capital-labor ratio and average wage. The number of observations in columns 2-4 and } 6-8 \text { are less } \\
\text { than the one in columns } 1 \text { and } 5 \text { due to the missing wage information for some firms in our sample. }\end{array}$} \\
\hline
\end{tabular}

production function that is time invariant). In an alternative simple set of instruments, we use the previous-year level of tariffs to instrument the changes in tariffs and obtain similar results.

One concern of the instrumental variable approach is the weak instrument. Our firststage tests reveal that our instruments explain $82-83 \%$ of the input tariff variation and $52-54 \%$ of the output tariff variation even after excluding the other exogenous variables for the sample of ordinary trade. Also the F-statistics show very high value. This suggests that we can reject the null hypothesis that our instruments are weak.

Except for the separate statistic for input and output tariff changes in the first-stage, we also conduct two joint tests to verify the quality of the instruments. The first diagnostic statistic for assessing the strength of identification is based on a Langrange-Multiplier (LM) test for underidentification using the Kleibergen and Paap (2006) rk statistic, because in our econometric model, the error term is assumed to be heteroskedastic and thus 
the usual canonical correlation likelihood ratio test (Anderson, 1984) is invalid. ${ }^{22}$ The Kleibergen and Paap (2006) rk statistic is to test whether an instrument is relevant to an endogenous variable (i.e., the change in tariffs). The null hypothesis that the model is underidentified is rejected at the 0.1 percent significance level.

The second diagnostic test we perform is the Kleibergen and Paap (2006) Wald statistic to check whether the instrument is weakly correlated with the endogenous variable. The Kleibergen and Paap (2006) Wald F-statistics provide strong evidence to reject the null hypothesis that the first stage is weakly identified at a highly significant level. That is to say, in all specifications, the instruments provide a good fit in the first stage, and perform as valid instruments.

Finally, when we use the full set of instruments, we also conduct the Hansen $J$ statistic to rule out the possibility of overidentifying restrictions. In most specifications with the simple set of instruments, the equation is exactly identified and there is no need to report the result of overidentification test. Only in specifications 3 and 7 when using the full set of instruments, we report the Hansen $J$ statistic. Column 3 of Table 6 for ordinary trade comfortably passes the Hansen test with a $p$-value of 0.237 and suggests that we cannot reject the null hypothesis that all instruments are uncorrelated with the error process. Column 7 of Table 6 for processing trade does not satisfy the conventional significance level, but should not affect our results because the coefficients on tariffs for processing trade are always insignificant. Overall, Table 6 confirms the previous finding that, for ordinary trade sample, the reductions in input tariffs significantly raise firm-product markups.

\section{Robustness}

Now we conduct several robustness checks to further corroborate the main results. In this section, we do not cluster error terms as we want to present more conservative results of processing trade that requires insignificant effect of input tariffs on markup adjustments. Nevertheless, most results remain valid even after clustering and would be mentioned in the notes to tables. In the previous section that presents our main results, insignificant effects for processing trade firms also remain unchanged without clustering error terms.

\footnotetext{
${ }^{22}$ In all of the specifications, the Cragg-Donald F statistic is also well above the critical values listed in Stock and Yogo (2005). However, we do not report them since critical values are for i.i.d. errors while in our econometric model the error term is assumed to be heteroskedastic.
} 
Table 7: Robustness: Alternative Estimates of Markup

\begin{tabular}{|c|c|c|c|c|c|c|c|c|}
\hline \multirow[t]{3}{*}{ Dependent variable: } & \multicolumn{4}{|c|}{ Firm-product-level markup } & \multicolumn{4}{|c|}{ Firm-level markup } \\
\hline & $(1)$ & $(2)$ & $(3)$ & (4) & $(5)$ & $(6)$ & $(7)$ & $(8)$ \\
\hline & \multicolumn{2}{|c|}{ Ordinary Trade } & \multicolumn{2}{|c|}{ Processing Trade } & \multicolumn{2}{|c|}{ Ordinary Trade } & \multicolumn{2}{|c|}{ Processing Trade } \\
\hline Input tariff & $\begin{array}{c}-2.860 * * * \\
(0.676)\end{array}$ & $\begin{array}{c}-2.628^{* * *} \\
(0.677)\end{array}$ & $\begin{array}{c}0.885 \\
(0.688)\end{array}$ & $\begin{array}{c}0.772 \\
(0.694)\end{array}$ & $\begin{array}{c}-0.435^{* * *} \\
(0.085)\end{array}$ & $\begin{array}{c}-0.496 * * * \\
(0.037)\end{array}$ & $\begin{array}{l}-0.209 \\
(0.246)\end{array}$ & $\begin{array}{l}-0.124 \\
(0.118)\end{array}$ \\
\hline Output tariff & $\begin{array}{c}1.178^{* * *} \\
(0.390)\end{array}$ & $\begin{array}{c}1.182^{* * *} \\
(0.390)\end{array}$ & $\begin{array}{c}-1.510^{* * *} \\
(0.361)\end{array}$ & $\begin{array}{c}-1.370^{* * *} \\
(0.365)\end{array}$ & $\begin{array}{c}0.142^{* * *} \\
(0.050)\end{array}$ & $\begin{array}{c}0.210^{* * *} \\
(0.021)\end{array}$ & $\begin{array}{c}-0.011 \\
(0.115)\end{array}$ & $\begin{array}{c}0.119 * * \\
(0.056)\end{array}$ \\
\hline $\log (\mathrm{TFP})$ & & $\begin{array}{c}0.850 * * * \\
(0.027)\end{array}$ & & $\begin{array}{c}0.791^{* * *} \\
(0.032)\end{array}$ & & $\begin{array}{c}0.890 * * * \\
(0.002)\end{array}$ & & $\begin{array}{c}0.840^{* * *} \\
(0.006)\end{array}$ \\
\hline Other Firm-level controls & NO & YES & NO & YES & NO & YES & NO & YES \\
\hline Industry-level controls & $\mathrm{NO}$ & YES & NO & YES & NO & YES & $\mathrm{NO}$ & YES \\
\hline Year Fixed Effect & YES & YES & YES & YES & YES & YES & YES & YES \\
\hline Industry Fixed Effect & YES & YES & YES & YES & YES & YES & YES & YES \\
\hline Firm-Product Fixed Effect & YES & YES & YES & YES & YES & YES & YES & YES \\
\hline Observations & 612222 & 611817 & 182531 & 182369 & 126358 & 126260 & 12888 & 12872 \\
\hline R-squared & .773 & .775 & .772 & .774 & .668 & .939 & .756 & .945 \\
\hline \multicolumn{9}{|c|}{$\begin{array}{l}\text { Notes: }{ }^{* *} \mathrm{p}<0.01,{ }^{* *} \mathrm{p}<0.05,{ }^{*} \mathrm{p}<0.1 \text {. Specifications } 1-2 \text { and } 5-6 \text { use ordinary trade observations and specifications } \\
3-4 \text { and } 7-8 \text { use processing trade observations. Specifications } 1-4 \text { use the firm-product-level markup with export quantity } \\
\text { projection, and specifications } 5-8 \text { use the firm-level markup. Other firm-level controls include firm size (measured } \\
\text { by employment), capital-labor ratio and average wage; industry-level controls include industry average wage, capital } \\
\text { intensity, and Herfindahl index at } 4 \text {-digit CIC industry level each year. Robust standard errors reported in parentheses } \\
\text { is not clustered. If we cluster at the industry-year level, the coefficients on input tariff in columns } 1-2 \text { and } 5 \text { are still } \\
\text { significant, and the one in column } 6 \text { would be significant at } 12 \% \text { level. The number of observations in even columns are } \\
\text { less than the one in odd columns due to the missing wage information for some firms in our sample. When estimating } \\
\text { alternative measures of markups, the solution to the systems of equations differ from the previous one as described in } \\
\text { Section } 4.3 \text { and thus yields different sample size. }\end{array}$} \\
\hline
\end{tabular}

\subsection{Alternative estimates of markup}

In the main results we use estimates of markup when projecting deflated export value instead of output quantity on all inputs, output and input tariffs, the output price, processing trade dummies, the interaction terms of processing trade dummies and input/output tariffs, region-industry-product dummies and time fixed effects. However, we do have quantity of exported product. Thus, we also project export quantity for each exported product $h$ and then obtain another set of estimated markups. Table 7 reports results using alternative estimates of markups with export quantity projection in columns 1-4. Again, it clearly presents the contrast between ordinary trade and processing trade: a cut of $1 \%$ input tariffs increase markups by $2-3 \%$ for ordinary trade observations while this effect is absent for processing trade observations. In columns 4-8, we report the results using firm-level markup as dependent variable which is estimated following De Loecker and Warzynski (2012)'s method (see Appendix A for detail) and the main results still hold. In all specifications of Table 7 , input tariffs only impact markups under 
ordinary trade and have no significant effect on markups under processing trade. Table 7 also reports that the more productive firms always charge higher markups which again confirms Lemma 1.

Table 8: Robustness with Firm-level Tariffs

Dependent variable: Firm-product markup

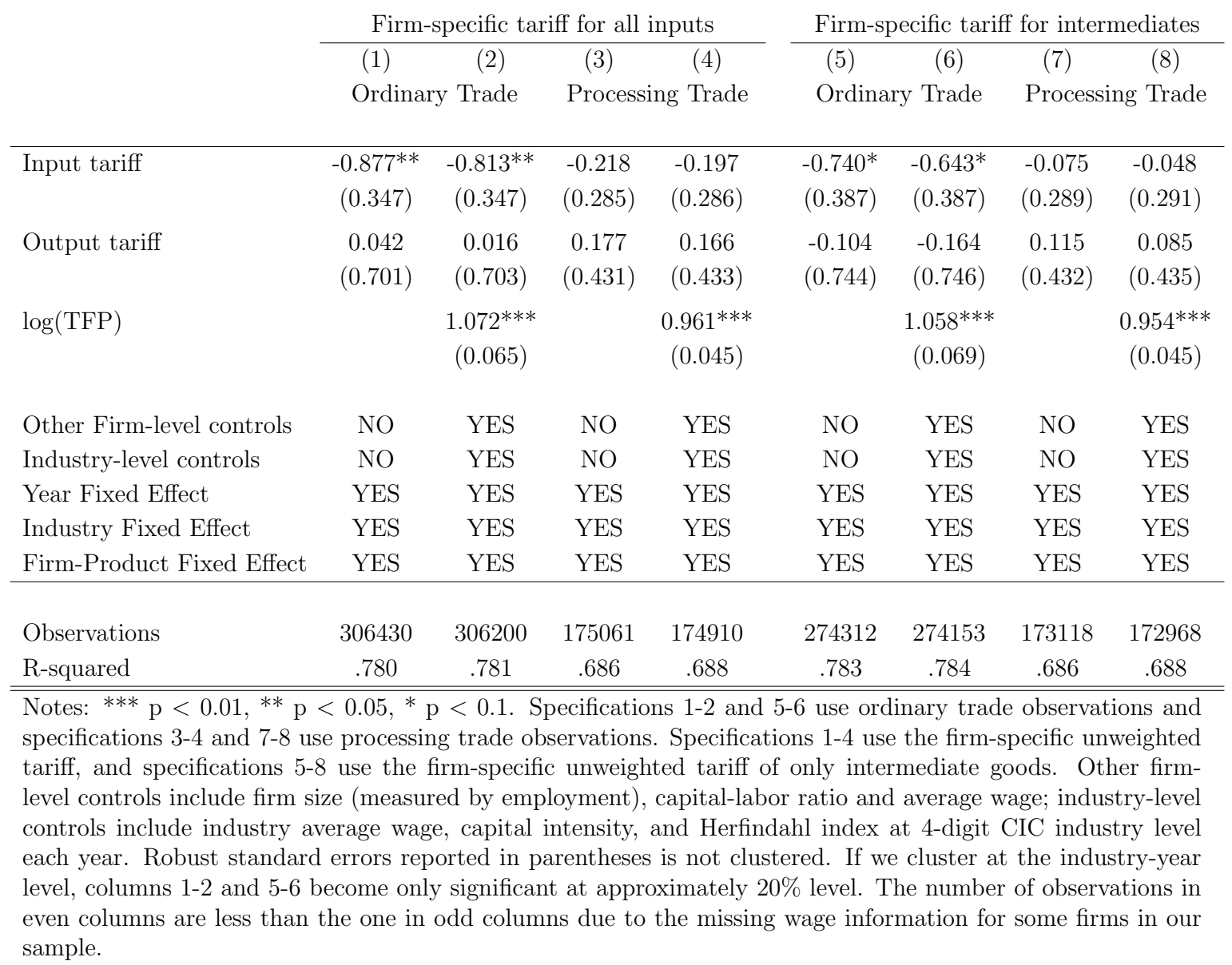

\subsection{Firm-level tariffs}

Since our model describes a firm's behavior in adjusting its markup when facing input tariff reductions, it is helpful to compute firm-level tariff measures to better employ information on the exact bundle of imported inputs by each individual firm. The firmlevel tariff measures can provide high resolution to the firm-specific intensive margin effects of tariff reduction (Fan, Li and Yeaple, forthcoming), and thus complement our previous results using industry input tariffs. Columns 1-4 in Table 8 report results using firm-specific unweighted input tariffs of all imported inputs and columns 5-8 present the results with firm-specific unweighted input tariffs of only intermediate inputs. It is 
not surprising that firm-level input tariffs show smaller effect than industry input tariffs (columns 1-2 in Table 8 vs. the baseline results as shown by columns $2-3$ in Table 1 ) because some firms may use intermediate inputs that are imported by other firms within the same industry and those are captured by industry input tariffs but not by firm-specific input tariffs. Also, when we restrict input bundles to only intermediate goods, the effect of input tariffs remains similar (see columns 5-6 vs. columns 1-2 in Table 8). Again, the effect of input tariffs only work through ordinary trade but not apply to processing trade.

\subsection{Sensitivity to exchange rates and across firm ownership}

Now we show that our results are not driven by the exchange rate movements between Chinese currency, Renminbi (hereafter RMB), and other currencies. Since RMB experienced a substantial appreciation in late 2005, we dropped data of 2005 and 2006, and conduct a robustness check only based on the sample of pre-appreciation period in 20002004. The results are reported in columns 1-4 in Table 9 and again confirm that our main findings are not driven by the exchange rate movement.

One might be also concerned with the presence of the state-owned companies in China. Also there are many foreign invested and joint ventures among Chinese firms. Those firms may receive more favorable treatments from the government than domestic private firms. Also some state-owned firms may not be purely profit oriented but for instance, employment and size oriented. Although in the baseline regressions we already control for firm size effect, we do not explicitly address the firm ownership issue which might potentially affect firms' behavior in adjusting markups. Therefore, to address this concern, we re-conduct our baseline regressions for ordinary and processing trade with firm ownership type fixed effects (measured by the firm registration type in China) and report results in columns 5-8 in Table 9. The firm ownership types include SOEs, multinational companies, joint ventures, domestic private firms, collective enterprises, etc. The results confirm our previous finding that input tariff reductions raise markups only for ordinary trade firms and more productive firms set higher markups regardless of ordinary or processing trade.

\section{Conclusion}

In this paper, we uncover patterns of markup adjustments under input-trade liberalization that strongly suggest that access to imported intermediate inputs can substantially increase the market power of firms. We first document stylized facts regarding China's input-trade liberalization and the markup adjustments by trade regime. We then devised an econometric model from a simple analytical framework of variable markup and access 
Table 9: Sensitivity to exchange rates and firm ownership types

Dependent variable: Firm-product markup

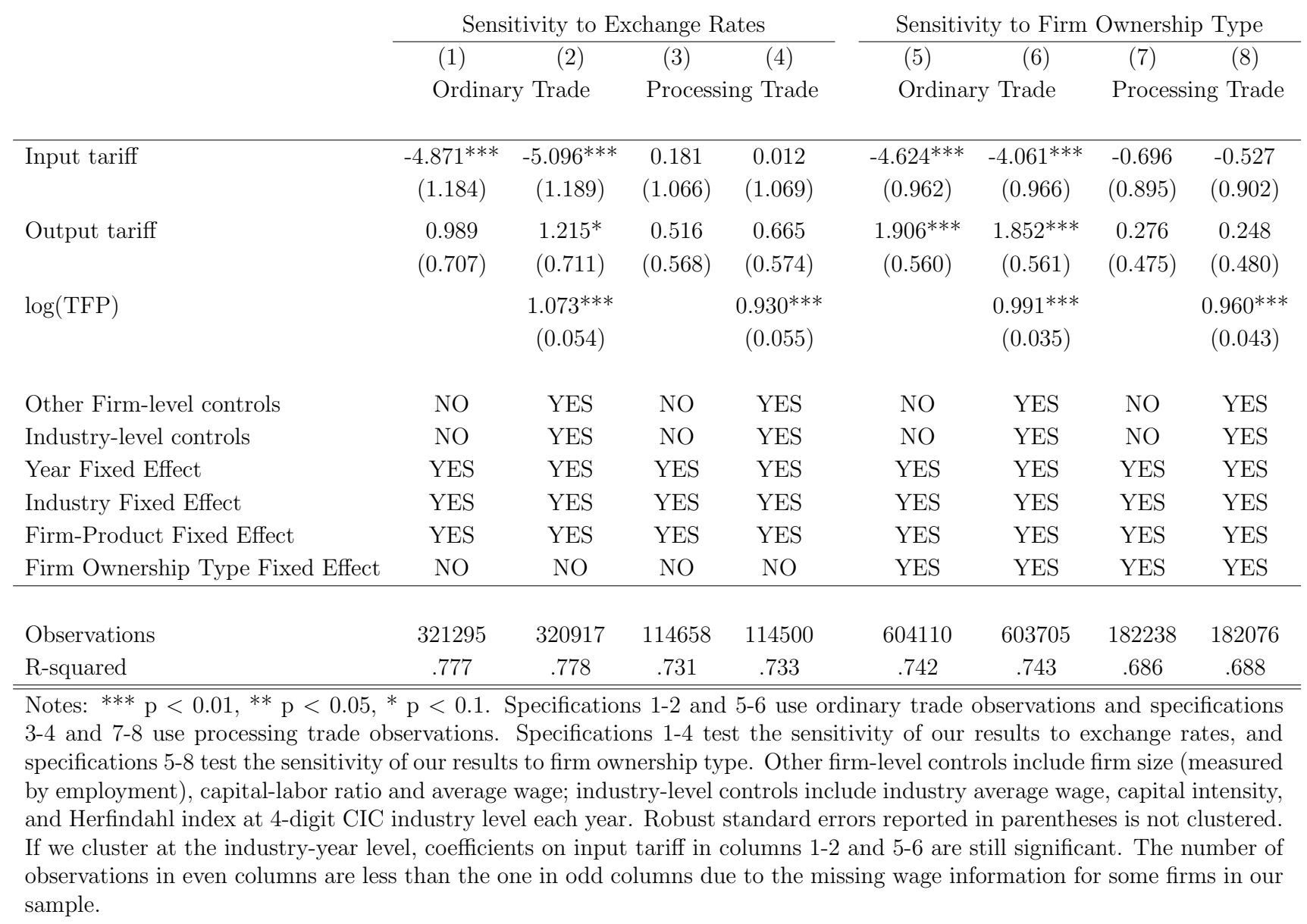

to imported intermediates. Estimating this model on Chinese data during China's WTO accession period, we find strong and robust evidence that the ordinary trade firms that pay import tariffs significantly raise their product markups after input tariff reductions, while processing trade firms do not. The underlying mechanism using marginal cost and import dependence is supported by empirical evidence from Chinese data.

Our study presents the revisit of the long-standing imports-as-market-discipline hypothesis and contributes to a vibrant literature that examines the impact of trade reforms on efficient allocation of resources across firms, the literature that links improved access to imported intermediate inputs to superior firm performance, and the literature that explores the different responses of ordinary trade versus processing trade firms. It would be interesting to further assess the resource reallocation and markup adjustment across core versus non-core products within multi-product firm and its relationship with trade liberalization. Also when taking into account the dynamic behavior of firm markup ad- 
justment, it would be fruitful to adopt a more structural approach jointly estimating markup adjustment with endogenous quality choice. Nevertheless, we believe that incorporating endogenous quality into the current model would not change the predictions on markup adjustment but may affect the effect on prices. It would be also interesting in exploring the distributional effect of markup adjustment across different types of firms when responding to trade liberalization. Those are left for future research. 


\section{References}

Amiti, Mary, and Amit K. Khandelwal. 2013. "Import Competition and Quality Upgrading." The Review of Economics and Statistics, 95(2): 476-490.

Amiti, Mary, and Donald R. Davis. 2012. "Trade, Firms, and Wages: Theory and Evidence." Review of Economic Studies, 79(1): 1-36.

Amiti, Mary, and Jozef Konings. 2007. "Trade Liberalization, Intermediate Inputs, and Productivity: Evidence from Indonesia." American Economic Review, 97(5): 16111638.

Amiti, Mary, Oleg Itskhoki, and Jozef Konings. 2014. "Importers, Exporters, and Exchange Rate Disconnect." American Economic Review, 104(7): 1942-78.

Anderson, T. W. 1984. An introduction to multivariate statistical analysis. Wiley series in probability and mathematical statistics. 2 ed., New York:Wiley. T.W. Anderson; ;25 cm; Includes index; Bibliography: p. 643-665.

Arkolakis, Costas, Arnaud Costinot, Dave Donaldson, and Andrés RodríguezClare. 2012. "The Elusive Pro-Competitive Effects of Trade." Massachusetts Institute of Technology working paper.

Bernard, Andrew B., Stephen J. Redding, and Peter K. Schott. 2010. "MultipleProduct Firms and Product Switching." American Economic Review, 100(1): 70-97.

Brandt, Loren, Johannes Van Biesebroeck, and Yifan Zhang. 2012. "Creative Accounting or Creative Destruction? Firm-level Productivity Growth in Chinese Manufacturing." Journal of Development Economics, 97(2): 339-351.

Cai, Hongbin, and Qiao Liu. 2009. "Competition and Corporate Tax Avoidance: Evidence from Chinese Industrial Firms." Economic Journal, 119(537): 764-795.

Chen, Natalie, Jean Imbs, and Andrew Scott. 2009. "The dynamics of trade and competition." Journal of International Economics, 77(1): 50-62.

de Blas, Beatriz, and Katheryn Niles Russ. forthcoming. "Understanding Markups in the Open Economy under Bertrand Competition." AEJ: Macroeconomics.

De Loecker, Jan, and Frederic Warzynski. 2012. "Markups and Firm-Level Export Status." American Economic Review, 102(6): 2437-71.

De Loecker, Jan, Pinelopi K. Goldberg, Amit K. Khandelwal, and Nina Pavcnik. 2014. "Prices, Markups and Trade Reform." Unpublished manuscript. 
Fan, Haichao, Edwin L.-C. Lai, and Yao Amber Li. forthcoming. "Credit Constraints, Quality, and Export Prices: Theory and Evidence from China." Journal of Comparative Economics.

Fan, Haichao, Yao Amber Li, and Stephen R. Yeaple. forthcoming. "Trade Liberalization, Quality, and Export Prices." Review of Economics and Statistics.

Feenstra, Robert C. 2003. "A homothetic utility function for monopolistic competition models, without constant price elasticity." Economics Letters, 78(1): 79-86.

Goldberg, Pinelopi Koujianou, Amit Kumar Khandelwal, Nina Pavcnik, and Petia Topalova. 2010. "Imported Intermediate Inputs and Domestic Product Growth: Evidence from India." The Quarterly Journal of Economics, 125(4): 1727-1767.

Goldberg, Pinelopi Koujianou, and Nina Pavcnik. 2005. "Trade, wages, and the political economy of trade protection: evidence from the Colombian trade reforms." Journal of International Economics, 66(1): 75-105.

Gopinath, Gita, and Brent Neiman. 2014. "Trade Adjustment and Productivity in Large Crises." American Economic Review, 104(3): 793-831.

Halpern, László, Miklós Koren, and Adam Szeidl. 2011. "Imported Inputs and Productivity." Center for Firms in the Global Economy CeFiG Working Papers 8.

Helpman, Elhanan, and Paul Robin Krugman. 1989. Trade Policy and Market Structure. Cambridge, MA:The MIT Press.

Kasahara, Hiroyuki, and Joel Rodrigue. 2008. "Does the use of imported intermediates increase productivity? Plant-level evidence." Journal of Development Economics, 87(1): 106-118.

Kleibergen, Frank, and Richard Paap. 2006. "Generalized reduced rank tests using the singular value decomposition." Journal of Econometrics, 133(1): 97-126.

Konings, Jozef, Patrick Van Cayseele, and Frederic Warzynski. 2001. "The dynamics of industrial mark-ups in two small open economies: does national competition policy matter?" International Journal of Industrial Organization, 19(5): 841-859.

Krugman, Paul R. 1979. "Increasing returns, monopolistic competition, and international trade." Journal of International Economics, 9(4): 469-479.

Levinsohn, James. 1993. "Testing the imports-as-market-discipline hypothesis." Journal of International Economics, 35(1-2): 1-22. 
Levinsohn, James, and Amil Petrin. 2003. "Estimating production functions using Inputs to Control for Unobservables." Review of Economic Studies, 70: 317-341.

Manova, Kalina, and Zhihong Yu. 2014. "Firms and Credit Constraints along the Global Value Chain: Processing Trade in China." unpublished manuscript, 15(3): 0811 .

Manova, Kalina, and Zhiwei Zhang. 2012. "Export Prices Across Firms and Destinations." The Quarterly Journal of Economics, 127: 379-436.

Ottaviano, Gianmarco, Takatoshi Tabuchi, and Jacques-François Thisse. 2002. "Agglomeration and Trade Revisited." International Economic Review, 43(2): 409-436.

Rodrik, Dani. 1988. "Imperfect Competition, Scale Economies, and Trade Policy in Developing Countries." In Trade Policy Issues and Empirical Analysis., ed. R. E. Baldwin. Chicago, IL.:University of Chicago Press.

Stock, James H., and Motohiro Yogo. 2005. "Testing for Weak Instruments in Linear IV Regression." In Identification and Inference for Econometric Models: Essays in Honor of Thomas Rothenberg. , ed. Donald W. K. Andrews and James H. Stock, 80-108. New York: Cambridge University Press.

Topalova, Petia, and Amit Khandelwal. 2011. "Trade Liberalization and Firm Productivity: The Case of India." The Review of Economics and Statistics, 93(3): 9951009 .

Trefler, Daniel. 2004. "The Long and Short of the Canada-U. S. Free Trade Agreement." American Economic Review, 94(4): 870-895.

Yu, Miaojie. forthcoming. "Processing Trade, Firms Productivity, and Tariff Reductions: Evidence from Chinese Products." Economic Journal. 


\section{Appendix}

Table A.1: Markup of Chinese Firms (by Sector)

\begin{tabular}{|c|c|c|c|c|}
\hline \multirow[t]{2}{*}{ Sector (2-digit industry code) } & \multicolumn{2}{|c|}{ Ordinary trade } & \multicolumn{2}{|c|}{ Processing trade } \\
\hline & Mean & Median & Mean & Median \\
\hline Processing of Food from Agricultural Products (13) & 2.0450 & 1.2067 & 2.0165 & 1.3208 \\
\hline Foods $(14)$ & 1.4972 & 1.2021 & 1.5964 & 1.2306 \\
\hline Beverages (15) & 2.5045 & 1.3270 & 1.4277 & 1.1750 \\
\hline Textile (17) & 1.7227 & 1.1593 & 1.8219 & 1.2461 \\
\hline Wearing Apparel, Footware, and Caps (18) & 1.4498 & 0.8649 & 1.3958 & 0.7592 \\
\hline Leather, Fur, Feather and Related Products (19) & 1.8603 & 1.1679 & 1.8278 & 1.1817 \\
\hline $\begin{array}{l}\text { Processing of Timber, Manufacture of Wood, Bamboo, } \\
\text { Rattan, Palm, and Straw Products (20) }\end{array}$ & 2.6750 & 1.2815 & 2.7146 & 1.2596 \\
\hline Furniture (21) & 1.8384 & 1.0555 & 1.9159 & 1.1848 \\
\hline Paper and Paper Products (22) & 1.6130 & 1.0848 & 1.8281 & 1.0873 \\
\hline Printing, Reproduction of Recording Media (23) & 1.8859 & 1.1872 & 1.7011 & 1.0630 \\
\hline Articles For Culture, Education and Sport Activity (24) & 2.2605 & 1.2431 & 1.7428 & 1.1626 \\
\hline Petroleum, Coking, Processing of Nuclear Fuel (25) & 1.3480 & 1.1615 & 2.2244 & 1.1849 \\
\hline Raw Chemical Materials and Chemical Products (26) & 1.6522 & 1.2078 & 1.6898 & 1.1741 \\
\hline Medicines (27) & 1.3422 & 1.0015 & 1.4858 & 1.1215 \\
\hline Chemical Fibers (28) & 1.5784 & 1.1410 & 1.7065 & 1.2355 \\
\hline Rubber (29) & 1.6581 & 1.1055 & 1.4277 & 1.1435 \\
\hline Plastics (30) & 1.9717 & 1.1261 & 1.6322 & 1.1093 \\
\hline Non-metallic Mineral Products (31) & 1.4751 & 1.0426 & 1.3539 & 1.1845 \\
\hline Smelting and Pressing of Ferrous Metals (32) & 1.3361 & 1.2466 & 1.2662 & 1.1791 \\
\hline Smelting and Pressing of Non-ferrous Metals (33) & 1.2870 & 1.1548 & 1.2596 & 1.1621 \\
\hline Metal Products $(34)$ & 1.7072 & 1.0648 & 1.4641 & 1.1038 \\
\hline General Purpose Machinery (35) & 2.1401 & 1.1997 & 1.9255 & 1.1849 \\
\hline Special Purpose Machinery (36) & 1.5317 & 1.1697 & 1.7206 & 1.2741 \\
\hline Transport Equipment (37) & 2.5295 & 1.4310 & 2.0427 & 1.3328 \\
\hline Electrical Machinery and Equipment (39) & 2.0315 & 1.2801 & 1.6834 & 1.1746 \\
\hline Communication Equipment, Computers and Other Electronic Equipment (40) & 3.0670 & 1.3360 & 2.4403 & 1.2429 \\
\hline Measuring Instruments and Machinery for Cultural Activity and Office Work (41) & 1.7948 & 1.0809 & 1.4879 & 1.0812 \\
\hline Artwork and Other Manufacturing (42) & 2.1033 & 1.0828 & 2.0569 & 1.2184 \\
\hline
\end{tabular}

Notes: Table displays the mean and median markup by 2 digit sector for the sample of ordinary trade firms and processing trade firms in 2000-2006. We trim observations with markup lower or higher than 2nd and 98th percentile within each sector. 


\section{A Measure of firm-level markup}

Following De Loecker and Warzynski (2012) we deal with the unobserved productivity shocks $\varphi_{f t}$ in the production function, equation (12), which are potentially correlated with input choices. As in Levinsohn and Petrin (2003), these shocks can be proxied via the material demand:

$$
m_{f t}=m_{t}\left(k_{f t}, \varphi_{f t}, \boldsymbol{z}_{f t}\right)
$$

where the firm's material demand depends on its capital stock $k_{f t}$, its productivity $\varphi_{f t}$ and other variables that potentially affect the firm's choice of materials in the vector $\boldsymbol{z}_{f t}$. These variables are WTO status, import/export status and input/output tariffs. Assuming that A.1 is monotonic in $\varphi_{f t}$ (in particular, strictly increasing in $\varphi_{f t}$ ) we can invert this function to proxy for productivity shocks in the production function estimation:

$$
\varphi_{f t}=h_{t}\left(k_{f t}, m_{f t}, \boldsymbol{z}_{f t}\right)
$$

Replacing the productivity shocks $\varphi_{f t}$ by equation (A.2) and expanding the general function $f\left(x_{f t} ; \beta\right)$ with the translog production function we can rewrite the production function as:

$$
\begin{aligned}
q_{f t}= & \beta_{l} l_{f t}+\beta_{m} m_{f t}+\beta_{k} k_{f t}+\beta_{l l} l_{f t}^{2}+\beta_{m m} m_{f t}^{2}+\beta_{k k} k_{f t}^{2} \\
& +\beta_{l m} l_{f t} m_{f t}+\beta_{m k} m_{f t} k_{f t}+\beta_{k l} k_{f t} l_{f t}+h_{t}\left(k_{f t}, m_{f t}, \boldsymbol{z}_{f t}\right)+\epsilon_{f t} \\
= & \phi\left(l_{f t}, k_{f t}, m_{f t}, \boldsymbol{z}_{f t}\right)+\epsilon_{f t}
\end{aligned}
$$

Approximating $h_{t}\left(k_{f t}, m_{f t}, \boldsymbol{z}_{f t}\right)$ with a polynomial series in $k_{f t}, m_{f t}$ and $\boldsymbol{z}_{f t}$, we can obtain estimated output $\widehat{q}_{f t}=\phi\left(l_{f t}, k_{f t}, m_{f t}, \boldsymbol{z}_{f t}\right)$ in the first stage. In the second stage, we estimate the vector of coefficients $\beta=\left(\beta_{l}, \beta_{m}, \beta_{k}, \beta_{l l}, \beta_{m m}, \beta_{k k}, \beta_{l m}, \beta_{l k}, \beta_{m k}\right)$ by relying on the law of motion for productivity. More precisely, for any particular vector $\beta$ we compute the corresponding productivity:

$$
\begin{aligned}
\varphi_{f t}(\beta)= & \widehat{q}_{f t}-\beta_{l} l_{f t}-\beta_{m} m_{f t}-\beta_{k} k_{f t}-\beta_{l l} l_{f t}^{2}-\beta_{m m} m_{f t}^{2} \\
& -\beta_{k k} k_{f t}^{2}-\beta_{l m} l_{f t} m_{f t}-\beta_{m k} m_{f t} k_{f t}-\beta_{k l} k_{f t} l_{f t}
\end{aligned}
$$

If we assume that productivity $\varphi_{f t}$ follows a Markov chain

$$
\varphi_{f t}=g\left(\varphi_{f t-1}\right)+\xi_{f t}
$$

then we can recover the innovation to productivity given $\beta, \xi_{f t}(\beta)$, by regressing $\varphi_{f t}(\beta)$ on its lag. Note that $\xi_{f t}$ is a function of the chosen vector $\beta$. Moreover, this innovation term $\xi_{f t}(\beta)$, by definition, is independent of all the lagged variables. In particular we 
have a set of moment conditions:

$$
E\left(\xi_{f t}(\beta) Y_{f t-1}\right)=0
$$

By noting that the capital stock $k_{f t}$ is predetermined, we choose

$$
Y_{f t-1}=\left(l_{f t-1}, m_{f t-1}, k_{f t}, l_{f t-1}^{2}, m_{f t-1}^{2}, k_{f t}^{2}, l_{f t-1} m_{f t-1}, m_{f t-1} k_{f t}, k_{f t} l_{f t-1}\right) .
$$

Equation (A.3) generates 9 moment conditions which allow us to estimate the vector of coefficients $\beta$.

The firm-level markup is defined as $\widehat{\mu}_{f t}=\ln \left(\widehat{\theta}_{f t}^{M} \frac{P_{f t} Q_{f t}}{P_{f t}^{M} V_{f t}^{M}}\right)$, where $\widehat{\theta}_{f t}^{M}$ is the output elasticity for materials; $P_{f t} Q_{f t}$ is the total sales; $P_{f t}^{M} V_{f t}^{M}$ is the value of total input materials. The material output elasticity, $\widehat{\theta}_{f t}^{M}$, is estimated as:

$$
\widehat{\theta}_{f t}^{M}=\widehat{\beta}_{m}+2 \widehat{\beta}_{m m} m_{f t}+\widehat{\beta}_{l m} l_{f t}+\widehat{\beta}_{m k} k_{f t}
$$

